\title{
A LATE PLEISTOCENE FOSSIL STORK (CICONIIFORMES: CICONIIDAE) FROM THE SANTA VITÓRIA FORMATION, SOUTHERN BRAZIL AND ITS PALEOENVIRONMENTAL SIGNIFICANCE
}

\author{
RENATO PEREIRA LOPES \\ Avenida Rio Grande, 45, caixa postal 15, 96207-000, Rio Grande-RS, Brazil. \\ paleonto_furg@yahoo.com.br \\ JAMIL CORREAA PEREIRA \\ Museu Coronel Tancredo Fernandes de Melo, Rua Barão do Rio Branco, 467, \\ 96230-000, Santa Vitória do Palmar, RS, Brazil. \\ jcorreapereira@bol.com.br \\ JORGE FERIGOLO \\ Seção de Paleontologia, Museu de Ciências Naturais, SEMA, Av. Salvador França, 1427, \\ 90690-000, Porto Alegre, RS, Brazil. \\ jorgeferigolo@gmail.com
}

\begin{abstract}
The avian fossil record of southern Brazil is scarce, consisting of few isolated remains. Here is described a ciconiid fossil from the assemblage of mammalian remains of the Santa Vitória Formation (SVF). The specimen is a cervical vertebra morphologically similar to Ciconia maguari (maguari stork), common in southern Brazil today. Nevertheless, its larger dimensions suggest that it could be either a morphotype of that species or another, extinct species. The taphonomic modifications of the vertebra result of a combination of autogenic and allogenic factors including the aquatic habit, shape and transportation by flowing water and burial in a shallow stream. The fossil-bearing sediment dated by luminescence was deposited during the late Pleistocene, at $37.9 \mathrm{ka} \mathrm{b} 2 \mathrm{k}$, and exhibits physical features indicating deposition under variable discharge and seasonal oscillations of the water table. The presence of an aquatic bird in these sediments indicates a period of increased precipitation, chronocorrelated to one of the millenial-scale warming pulses recorded in ice cores from Antarctica (Antarctic Isotope Maxima) that characterized the interstadial MIS 3. On the other hand, the dry and cold climate of the following glacial MIS 2 may have forced ciconiids and aquatic mammals to retreat to suitable areas (refugia), as indicated by their absence in the loess deposits (Cordão Formation) overlying the SVF, until returning during the Holocene when climate became wet and warm again. The results presented here increase the avian fossil record of southern Brazil and help understand the role of climate change on the distribution of ciconiid birds and other taxa during the Quaternary in southern South America.
\end{abstract}

Keywords: Ciconiidae, Santa Vitória Formation, taphonomy, MIS 3, paleoenvironment, paleoclimate.

RESUMO - O registro fóssil de aves do sul do Brasil é escasso e consiste de poucos elementos isolados. Aqui é descrito um fóssil de ciconídeo na assembleia de restos de mamíferos da Formação Santa Vitória. O espécime consiste de uma vértebra cervical morfologicamente similar a Ciconia maguari (joão-grande), comum atualmente no sul do Brasil. Entretanto, suas dimensões maiores sugerem que poderia ser um morfotipo daquela espécie ou outra espécie extinta. As modificações tafonômicas na vértebra resultam da combinação de fatores autogênicos e alogênicos incluindo o hábito aquático, forma e transporte por água corrente e soterramento em um riacho raso. O sedimento fossilífero datado por luminescência foi depositado no Neopleistoceno, há 37,9 ka, e exibe características que indicam deposição sob descarga variável e oscilações sazonais do lençol freático. A presença de uma ave aquática em sedimentos depositados por água indica um período de precipitação elevada, cronocorrelacionado a um dos pulsos quentes em escala milenial registrados em testemunhos de gelo da Antártica (Máximos Isotópicos Antárticos) que caracterizaram o interestadial MIS 3. Por outro lado, o clima frio e seco do glacial seguinte MIS 2 pode ter forçado os ciconídeos e mamíferos aquáticos a se retirarem para áreas adequadas (refúgios), como sugere sua ausência nos depósitos de loess (Formação Cordão) acima da FSV, até retornar durante o Holoceno, quando o clima se tornou úmido e quente novamente. Os resultados apresentados aqui ampliam o registro fóssil de aves do sul do Brasil e ajudam a compreender o papel das mudanças climáticas na distribuição de aves ciconídeas e outros táxons durante o Quaternário no sul da América do Sul.

Palavras-chave: Ciconiidae, Formação Santa Vitória, tafonomia, MIS 3, paleoambiente, paleoclima. 


\section{INTRODUCTION}

The modern avian fauna of South America is a mixture of autochthonous and allochthonous taxa, with a fossil record dating back to the Paleogene (Tambussi \& Degrange, 2013). Although the understanding of the Cenozoic history and dynamics of the South American avian faunas is affected by gaps in the fossil and geological record, it is recognized that the autochthonous taxa represent groups such as Tinamidae, Rheidae, Phorusrhacidae, Claornithidae, Anhimidae, Cathartidae, Teratornithidae, Falconidae Presbyornithidae and Pelecanidae, Galliformis, Phoenicopteriformis and Cariamiformis (Vuille, 1985; Tambussi \& Noriega, 1996; Tambussi \& Degrange, 2013) that were already established during the Paleogene, and evolved in isolation until the closure of the Isthmus of Panama led to the Great American Biotic Interchange (GABI) during the Plio-Pleistocene. The allochthonous group includes taxa that migrated from North America prior to the GABI (Cariamidae, Ciconiidae) and others that migrated to the south during the GABI, such as Burhimidae, Charadriidae, Anatidae, Laridae, Columbidae, Cracidae, Tytonidae, Strigidae, Phoenicopteridae, Jacanidae and Psittaciformes (Vuilleumer, 1985; Tambussi, 2011; Tambussi \& Degrange, 2013).

The Cenozoic avian fossil record of South America is rich and relatively abundant, although not as widespread as that of mammals. Most of the late Cenozoic fossils known from southern South America have been discovered along the Atlantic coast of the Province of Buenos Aires (Argentina) that encompasses sedimentary sequences ranging in age from the Miocene (Huayquerian) to the Pleistocene (Lujanian), whose fossil records show an increase of diversity in the avian faunas from the Huayquerian to the Montehermosan (Mio-Pliocene), followed by a decrease in the Chapadmalalan (Pliocene), and diversification from the Ensenadan (Pleistocene) to the Holocene (Tambussi et al., 1993).

In Pleistocene deposits of southern Brazil (Rio Grande do Sul State) the avian fossil record only consists of a tarsometatarsus of a ciconiid cf. Mycteria americana Linnaeus, 1758 (Ribeiro et al., 1995) and a fragment of a tibiotarsus of unknown affinities (Hsiou, 2009), both from the continental Touro Passo Formation, plus three cervical vertebrae and a partial tibiotarsus of albatrosses, cf. Thallasarche melanophris (Temminck, 1828) from fossiliferous concentrations on the continental shelf (Lopes et al., 2006). Here the first avian fossil from continental deposits of the coastal plain is presented, from Pleistocene sediments of the Santa Vitória Formation, a lithostratigraphic unit well-known for its rich fossil mammalian record (Lopes, 2013).

\section{GEOLOGICAL SETTING}

The fossil described here was found in deposits exposed along the banks of Chuy Creek, in the southern Coastal Plain of the State of Rio Grande do Sul (CPRS), in the County of Santa Vitória do Palmar. The creek flows along a flat lowland area that corresponds to the Lagoon System III
(Figure 1), a depositional system bounded to the west by the middle Pleistocene coastal Barrier II and to the east by the late Pleistocene Barrier III (Villwock \& Tomazelli, 1995). The fossil-bearing sediments were discovered in the 1960s, when Chuy Creek was further deepened for agriculture purposes (Paula Couto \& Cunha, 1965) and described as a lithostratigraphic unit named Santa Vitória Formation (SVF) by Soliani (1973).

The SVF overlies marine deposits interpreted as belonging to the Barrier II, and encompasses paleosoils, eolian and fossil-bearing fluvial deposits composed of fine to medium sand with some amounts (up to $20 \%$ ) of silt and clay. The fluvial deposits exposed along the banks of the creek consist

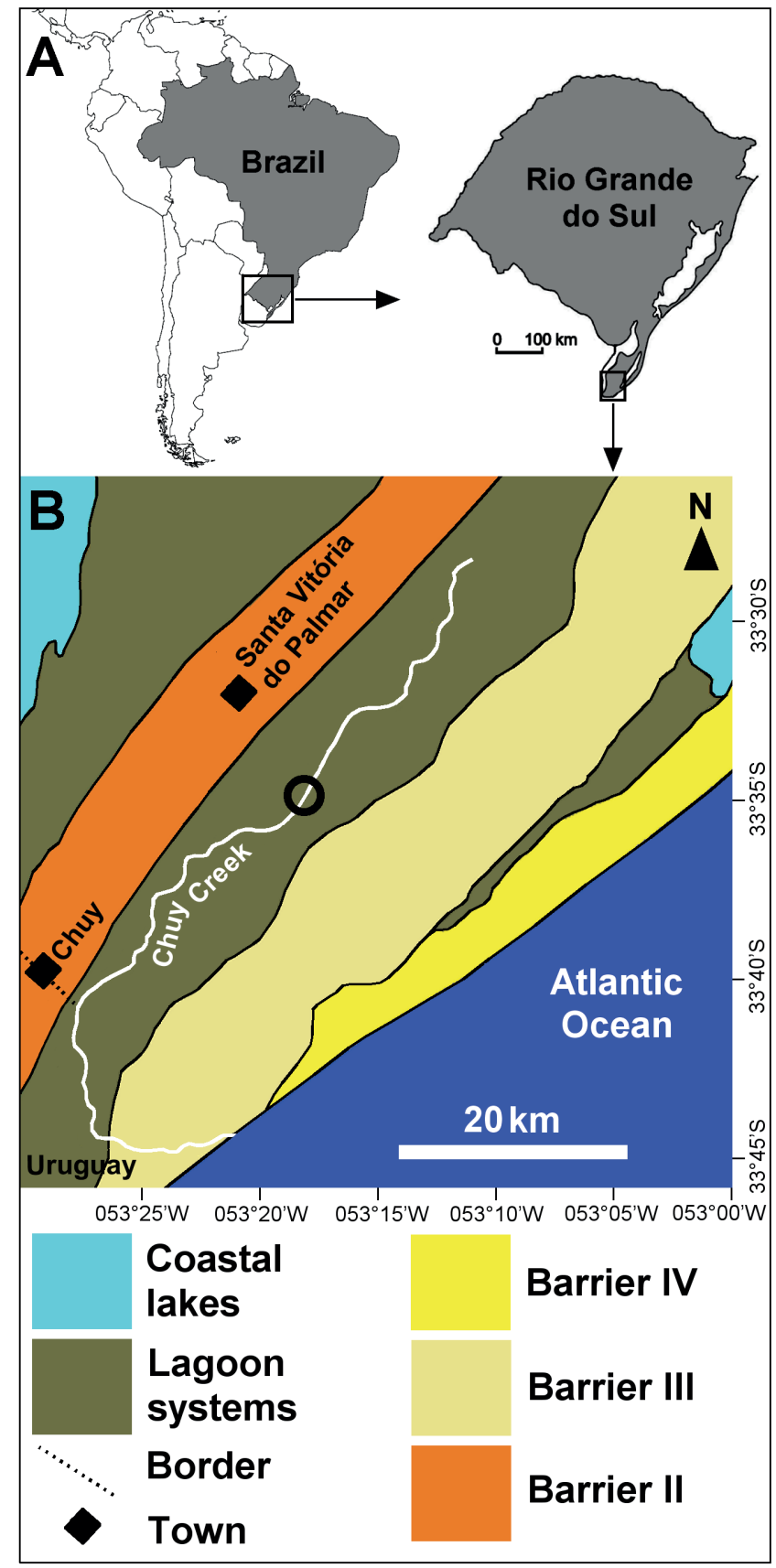

Figure 1.A, location of the study area in southern Brazil. B, geomorphological features of the study area, the location fossil-bearing outcrop is indicated by the black circle. 
of lens-shaped and tabular bodies formed by massive or subhorizontally-stratified muddy sand, measuring up to 40 $\mathrm{cm}$ in thickness and up to $10 \mathrm{~m}$ in length, and exhibit channel $(\mathbf{C H})$, lateral accretion (LA) and floodplain (FF) architectural elements (sensu Miall, 1985). The luminescence ages obtained from sediments and the electron spin resonance (ESR) ages from fossil teeth indicate that the SVF was deposited between $\sim 220$ and $\sim 30 \mathrm{ka}$ b2k (before year $2000 \mathrm{AD}$ according to the Greenland Ice Core Chronology 2005, Andersen et al., 2006) (Lopes et al., 2010; 2014a,b).

The SVF is overlained by the Cordão Formation $(\mathbf{C F})$, consisting a 1-2 meter-thick loess mantle composed of sandy to clayey silt. The luminescence ages indicate that the loess was deposited between $\sim 30$ and $\sim 10 \mathrm{ka} \mathrm{b} 2 \mathrm{k}$, under arid to semiarid climate as indicated by carbonate nodules (caliche) found in the lower CF along some parts of the banks (Lopes et $a l ., 2016 \mathrm{a})$. The uppermost $\sim 0.5-1 \mathrm{~m}$ of the CF is a chernozem formed in wetlands and streams as indicated by the presence of freshwater mollusks and diatom assemblages (Lopes et al., 2016a,b) under warm and humid climate, probably related to the Holocene climatic optimum, as suggested by ${ }^{14} \mathrm{C}$ ages from organic-rich sands overlying Pleistocene sediments obtained elsewhere in the southern CPRS (Lima et al., 2013; Caron, 2014).

The banks along the creek are mostly covered by vegetation nowadays, but an outcrop on the right bank exposed by erosion has yielded several fossils throughout the years. Most of these specimens were found among the colluvium removed by erosion and accumulated at the base of the bank, but a series of systematic excavations in the outcrop revealed several fossils preserved in situ, including the bird vertebra described here.

\section{Stratigraphy and depositional setting}

The bank reaches about $5 \mathrm{~m}$ above the creek bed at the location of the fossil-bearing outcrop (Figure 2A) and stretches for some $90 \mathrm{~m}$, but most of it is covered by plants. The fossils described here were found across a $\sim 10 \mathrm{~m}$-long portion of the outcrop that has been exposed by erosion. The base of the stratigraphic succession at the outcrop (Figure 2A) consists of the marine deposits of the Barrier II, formed by pale brown (colour 2.5Y 8/2 in the Munsell chart) fine sand with cross- and parallel bedding and the ichnofossil Ophiomorpha nodosa, with its top mottled by iron oxide and bioturbated by plant roots.

The overlying SVF measures about $1 \mathrm{~m}$ in thickness and two facies were recognized within it. The lower one (F1) is a $\sim 15$ centimeter-thick massive, pale brown $(2.5 \mathrm{Y} 8 / 3)$ clayey sand facies ( $\mathbf{c S m})$ stained yellow $(2.5 \mathrm{Y} 7 / 8)$ by precipitation of iron oxide (Figure 2B). Black subspherical masses of sand grains coated with iron-manganese and centimetric iron oxide nodules are common within it. Its uppermost portion is a centimetric layer of oxidized sandy clay ( $\mathbf{s C}$ ). The contact with the underlying Barrier II is sharp, and its upper contact is erosive. Because most of the outcrop is covered by vegetation the extent of this facies could not be determined yet, which difficult its interpretation, but its massive aspect, presence of iron and manganese oxides, and its stratigraphic position at the same level of a fluvial channel found some $20 \mathrm{~m}$ to the south (Figure 2C), suggests that it could have been deposited in the floodplain associated with that channel and afterward modified by weathering and pedogenesis.

The overlying facies (F2) contained the fossils described here (Figure 2B). It measures some $30 \mathrm{~cm}$ in thickness, and is bounded at its base by an erosive surface with centimetric mudclasts presumably reworked from the underlying F1. It consists of a pale yellow (5Y 8/4) massive fine clayey sand $(\mathbf{c S m})$ with distinct mottling in its upper portion because of the presence of iron oxide and iron-manganese masses. These occur as abundant small $(\leq 1$ centimeter) masses randomly distributed, but also forming a discrete horizontal line within the facies (Figure 2D) and a $\sim 5$ centimeter-thick concentration at its top. These physical features indicate that this facies was deposited in fluvial setting (floodplain, point bar or a shallow channel), possibly under intermittent flow, and later modified by weathering and incipient pedogenesis (see Discussion).

The sediments that conformably overlie F2 are quite similar, with iron-manganese masses and root traces, but no fossils have been found in it so far. The transition from the SVF to the CF above is gradual and marked by an increase in silt-sized particles.

\section{Fossil content}

All fossil specimens found in the outcrop were deposited in the paleontological collection of the Museu Coronel Tancredo Fernandes de Mello, in the town of Santa Vitória do Palmar.

Along the outcrop, the fossils were found in situ within the facies F1 (Figure 2B) or collected downslope among colluvium removed by erosion. The fossil assemblage consists of disarticulated elements, most of which are broken and/ or abraded (Figure 2E), and some exhibit surface cracks that indicate weathering prior to burial (Figures 2F, G). The fossils found in situ within the sediment matrix are isolated (i.e. not articulated or in contact with each other) and include unidentifiable fragments of larger skeletal elements, and recognizable elements including vertebrae, antlers, osteoderms and teeth. The osteoderms (Figures 2H, I, J) are the most complete specimens, common in mammalian fossil assemblages from the CPRS (Aires \& Lopes, 2012; Lopes \& Ferigolo, 2015).

The fossils that could be identified to the genus or species level include the notoungulate Toxodon platensis Owen, 1840 (Figure 2G), the pampatheriid Pampatherium humboldtii (Lund, 1839) (Figure 2H) and the glyptodontid Panochthus Burmeister, 1866 (Figure 2I). The presence of several osteoderms of the latter, including two still articulated, suggests that these may belong to one single individual. Several small osteoderms of mylodontid sloths (Figure 2J) were also recovered. Other remains have been found downslope in sediments eroded from this outcrop throughout the years, but the exact stratigraphic provenance of these is unknown.

The taphonomic differences among the fossils suggest distinct post mortem histories. The poor preservation of several remains indicate that these were subject to several 
cycles of deposition-exhumation-deposition controlled by fluvial processes, such as erosion of older deposits by channel migration and increased-decreased flow, therefore the fossil assemblage is probably time-averaged. On the other hand, the good state of preservation of the bird vertebra suggests that it was not transported for long distance/time or subject to postburial reworking. The broken portions exhibit the same color as the rest of the bone, which indicates that it was broken prior to diagenesis. The completeness of the vertebra indicates that it can be regarded as parautochthonous, i.e., transported and preserved within the same environmental setting in which the organism lived (Behrensmeyer, 1991), therefore it was probably deposited at the same time the fluvial deposit was active, which has important paleoenvironmental implications.

\section{Age}

In order to determine the age of the deposit, and indirectly of the vertebra, one sediment sample was collected at the stratigraphic level where the vertebra was excavated (Figure 2) for dating by optically-stimulated luminescence
(OSL). The sediment was extracted with a $50 \mathrm{~cm}$-long and 7 $\mathrm{cm}$-diameter PVC tube, and the analytical procedures were performed at the Datação, Comércio e Prestação de Serviços Ltda. (São Paulo, Brazil), using the 10-aliquot regeneration (SAR) protocol (Wallinga et al., 2002). The sample was opened under red light, treated with $20 \% \mathrm{H}_{2} \mathrm{O}_{2}, 20 \% \mathrm{HF}$ and $10 \% \mathrm{HCl}$, and then dried and sieved to obtain the 100-160 $\mu \mathrm{m}$ grain fraction. Part of the sediment was exposed to sunlight and then divided in several subsamples, which were irradiated using a ${ }^{60} \mathrm{Co}$ source at several predefined doses (Gy) to obtain the standard calibration curve. Fifteen subsamples were taken to individual calibration curves, which were compared with the standard.

The results of the OSL dating are shown in the Table 1. The age of $\sim 38 \mathrm{ka}$ is the youngest luminescence result obtained so far from the SVF, and it is within the range of ages from fossil mammalian teeth using the ESR method (Lopes et al., $2010 ; 2014 a)$. That age is in agreement with two OSL ages of 27.1 and 26 ka obtained from the overlying Cordão Formation (Lopes et al., 2016a).

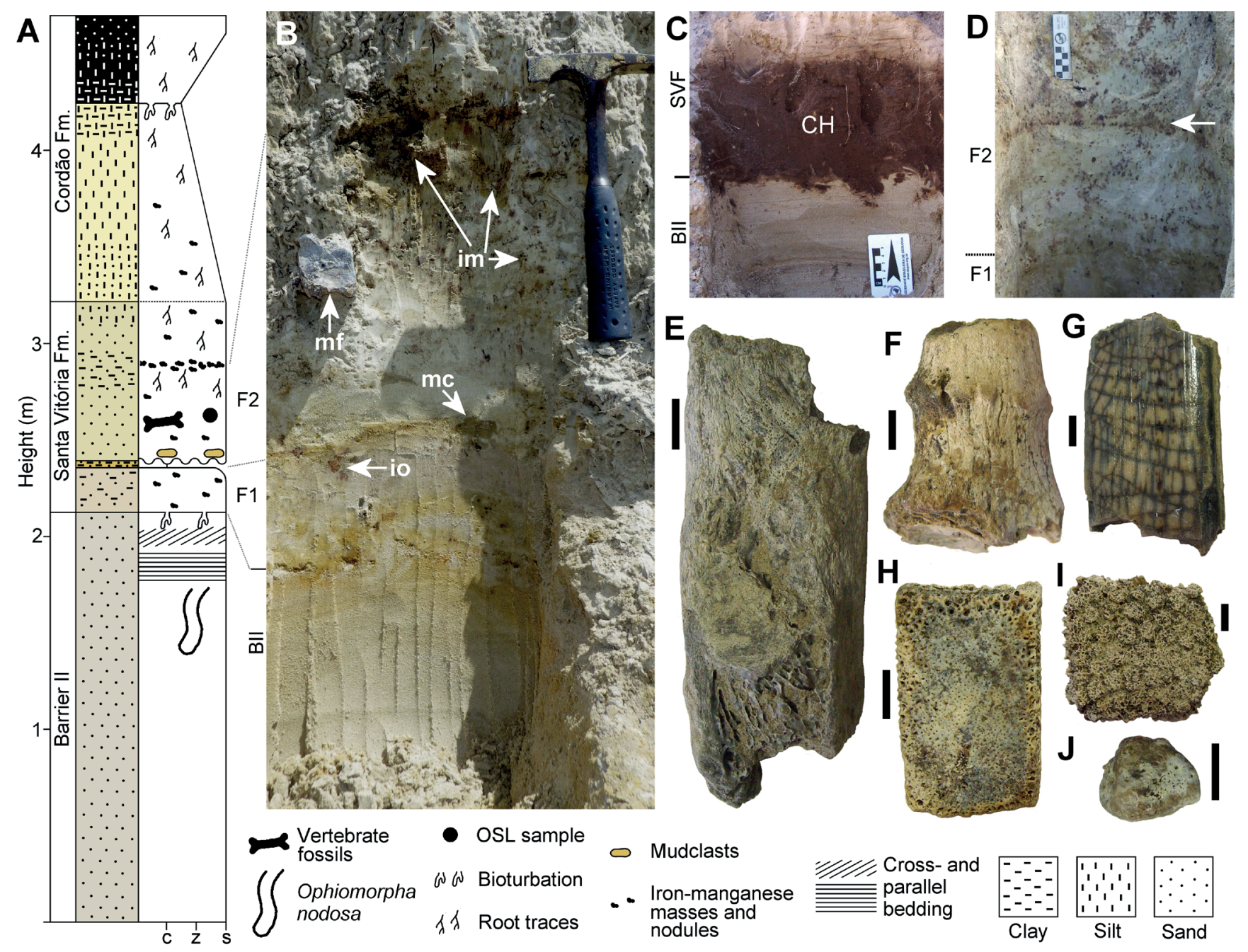

Figure 2. A, stratigraphic section of the fossil-bearing outcrop. B, close-up of the outcrop showing the two facies (F1 and F2) of the SVF, the indicated features include a mudclast (mc), iron-manganese masses (im), an iron oxide nodule (io) and a mammalian fossil (mf) in situ. $\mathbf{C}$, the fluvial channel (CH) at the same stratigraphic level of the facies F1. D, detail of the facies F2, the arrow indicates a line of iron-manganese masses. E, fragmented and abraded bone. F, incomplete antler of a cervid showing longitudinal cracks. G, molar of Toxodon platensis. Osteoderms of Pampatherium humboldtii (H), Panocthus sp. (I) and mylodontid sloth (J). Scale bars $=10 \mathrm{~mm}$. 
Table 1. Results of the OSL dating in the fossil-bearing sediments.

\begin{tabular}{lcccc}
\hline $\begin{array}{l}\text { Laboratory } \\
\text { no. }\end{array}$ & Sample & $\begin{array}{c}\text { Annual dose } \\
(\mu \text { Gy/year })\end{array}$ & $\begin{array}{c}\text { P } \\
(\mathrm{Gy})\end{array}$ & Age (years) \\
\hline 4578 & FSV-004 - 2m & $1,670 \pm 140$ & 63.2 & $37,900 \pm 5,080$ \\
\hline
\end{tabular}

\section{METHODS}

The morphology of the vertebra indicates that it belonged to a long-necked bird species, and in order to reach a taxonomic assignment it was compared with skeletal specimens deposited in the ornithological collections of the Museu de Ciências Naturais / Secretaria do Meio Ambiente e Infraestrutura (MCN/SEMA-RS), and the Museu de Ciência e Tecnologia / Pontifícia Universidade Católica do Rio Grande do Sul (MCT/PUC-RS).

The relative large size of the fossil vertebra led to its comparison with specimens of large-bodied birds found living today in the CPRS, which included herons (Ardea cocoi Linnaeus, 1766), swans (Coscoroba coscoroba Reichenbach, 1853 and Cygnus melancoryphus (Molina, 1782)), jabiru or marabou stork [Jabiru mycteria (Lichtenstein, 1819)], wood stork (Mycteria americana Linnaeus, 1758) and maguari stork (Ciconia maguary Linnaeus, 1758). Although the only skeleton of $J$. mycteria available for comparison does not have the complete cervical series, the remaining vertebrae are more robust than those of the other ciconiids. Nevertheless, the fossil specimen is morphologically more similar to $C$. maguari and M. americana than to swans. Although not all the examined skeletons of these taxa are complete, three specimens of C. maguari (MCN-O0073, O0281 and O700) and one of M. americana (MCN-O608) from the Museu de Ciências Naturais, and five C. maguari (MCT0574, 0751, 1448, 1908 and 1910) and one of M. americana (MCT1832) from the Museu de Ciência e Tecnologia have the vertebral series complete enough for comparison and measurement. In these specimens the cervical vertebra morphologically more similar to the fossil was chosen for comparative measurement. All measures were taken with a digital caliper with an error of $\pm 0.01 \mathrm{~mm}$, and are presented in millimeters. The morphology is described based on published references (Owen, 1866; Huxley, 1872; Parker, 1887; Bellairs \& Jenkin, 1960) and the anatomical terminology follows Baumel \& Witmer (1993).

\section{SYSTEMATIC PALEONTOLOGY}

\author{
AVES Linnaeus, 1758 \\ CICONIIFORMES (Bonaparte, 1854) \\ CICONIIDAE (Gray, 1840)
}

Ciconia Brisson, 1760

Ciconia sp.

(Figure 3)

Material. MCTFM-PV1090, cervical vertebra (Figure 3), paleontological collection of the Museu Coronel Tancredo Fernandes de Mello, in the town of Santa Vitória do Palmar.
Provenance and age. Right bank of Chuy Creek, fluvial deposit of the Santa Vitória Formation, Late Pleistocene (37,900 $\pm 5,080$ years), biostratigraphically correlated to the Lujanian Stage/Age sensu Cione and Tonni (1999).

Description and comparison. The vertebra is almost complete, with portions on the ventral area of the cranial end partially fragmented. The corpus vertebrae is heterocoelous, dorsoventrally compressed, with a marked longitudinal curvature that makes it ventrally concave in lateral norm. It is probably a vertebra from the intermediate sector of the cervical series (R2 of Boas, 1929), indicated by the reduced processi transversi, the wide open sulcus caroticus bounded laterally by a ventrally-oriented processus caroticus on each side and by the absence of the crista ventralis corporis (= hypapophysis), which is present in the cranial and caudal portions of the cervical series (Owen, 1866; Shufeldt, 1909; Baumel \& Witmer, 1993). The vertical diameter of the foramen vertebrale is wider at the middle than at both ends, but the horizontal diameter exhibits the opposite pattern, being narrower at the middle, a characteristic observed in storks (Owen, 1866, p. 41). Only the basal portion of the processus spinosus is preserved, but the broken portion suggests that its length was about half of that of the vertebra as in Ciconia maguari (in Mycteria americana it is shorter). The crista transverso-obliqua, a feature of long-necked birds (Baumel \& Witmer, 1993), is also broken at the confluence with the processus spinosus. The lamina arcocostalis and processus costalis (= pleurapophyses) on both sides are broken, therefore it is not possible to estimate how farther back these structures reached. However, it is apparent that the lamina arcocostales were dorsally confluent with the body at about mid-way between the posterior end of the $p$. spinosus and the zygapophysis caudalis, as observed in the recent specimens of C. maguari (Figure 4) and M. americana. The posterior margin of the ansa costotransversaria, at the confluence with the lamina arcocostalis, seems to have been located at about the mid-length of the vertebra as in C. maguari (Figure 4), whereas in M. americana the margin is positioned more anteriorly, at about $1 / 3$ of the length.

Other differences observed in the fossil vertebra include: the dorsal margin of the zygapophyses craniales are more rounded and less dorsally projected than in Ciconia maguari (see Figure 4C) and Mycteria americana. The cranial lacuna interzygapophysialis reaches more posteriorly than in $C$. maguari (Figure 4D) and M. americana, thus exposing the facies articularis cranialis in dorsal norm. The outline of the lacuna interzygapophysialis in dorsal norm exhibits a distinct notch at the confluence of the zygapophyses craniales with the lamina dorsalis arcus (Figure 4A) and one u-shaped notch in its the middle portion, which are absent in $C$. maguari (Figure 4D) but present in M. americana. Although the processus caroticus on both sides are broken, the ventral margin of each process was apparently projected laterally as in C. maguari (Figure 4A), forming a wide open sulcus caroticus, whereas in M. americana, the margin is more curved toward the midline, partially enclosing the sulcus caroticus. The arcus vertebralis as seen in caudal norm is 
A

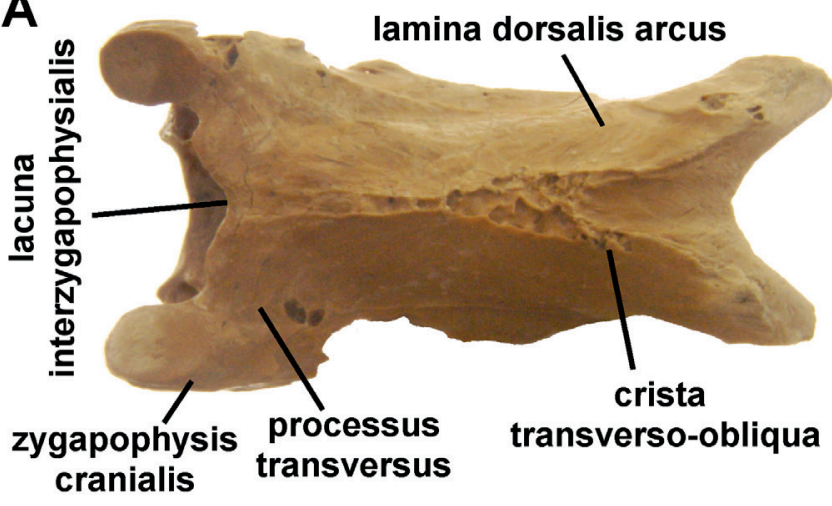

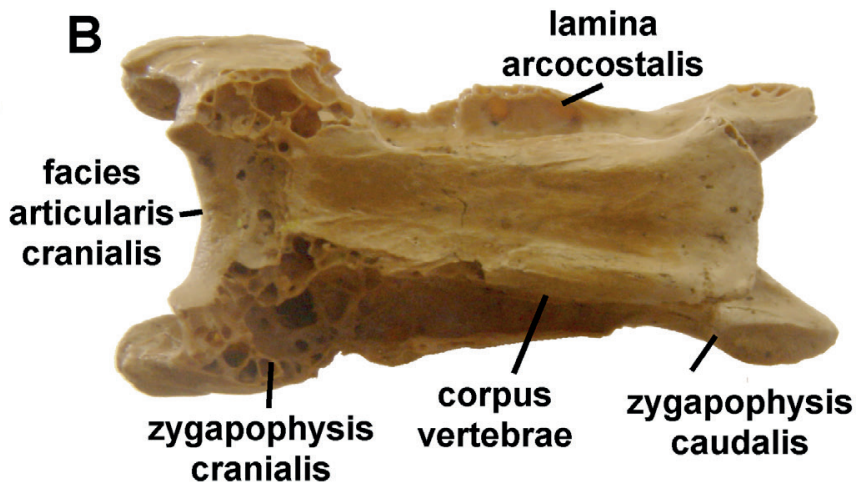

lamina arcocostalis
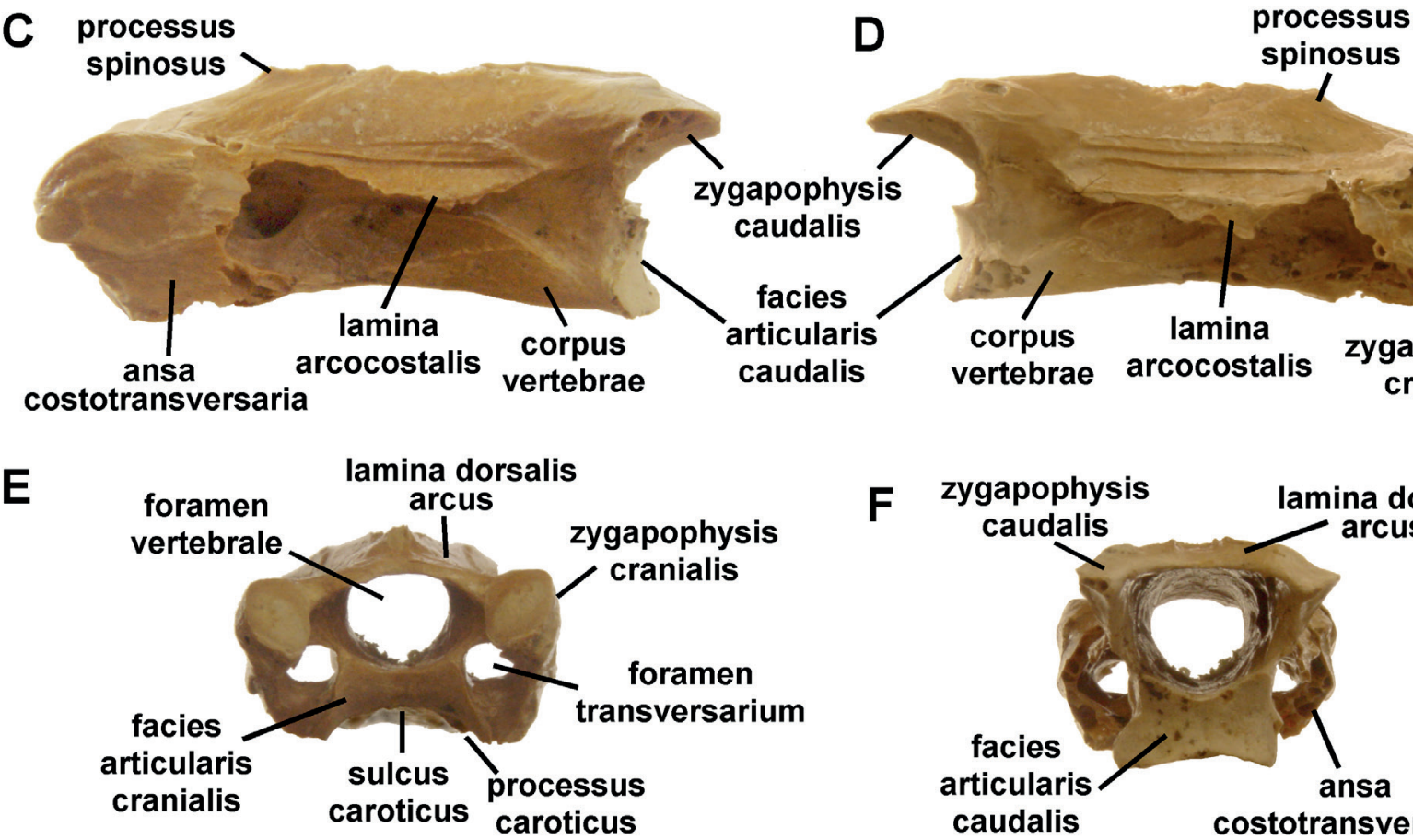

spinosus

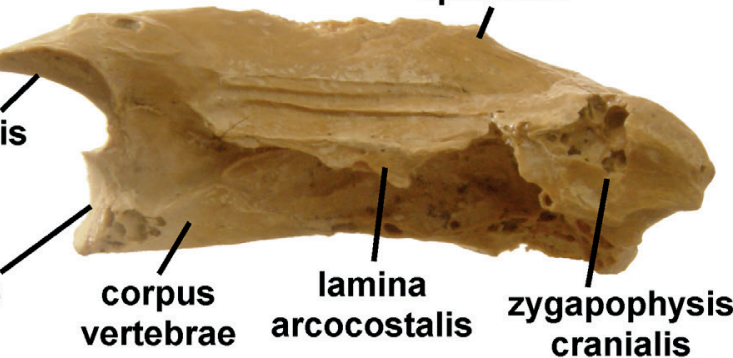

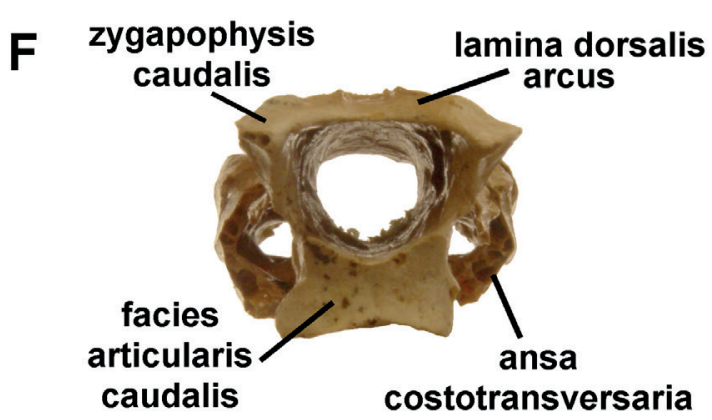

Figure 3. The specimen MCTFM-PV1090 in dorsal (A), ventral (B), left (C), right (D), cranial $(\mathbf{E})$ and caudal $(\mathbf{F})$ views. Scale bar $=10 \mathrm{~mm}$.

curved downward laterally, placing the articular facets of the zygapophysis caudales in a lower position, whereas it is almost flat in C. maguari and M. americana. The dorsal portion of each zygapophysis caudalis lacks the small tubercle (also absent in C. maguari) observed in M. americana. The diameter of the foramen vertebrale and foramina transversaria are proportionally larger, and the articular facets of the zygapophysis caudales are shorter (i.e. less caudally projected) in the fossil than in both $C$. maguari and $M$. americana. The facies articularis caudalis is dorsoventrally more compressed than in $C$. maguari, but taller than in $M$. americana, which also has the ventral margin much wider than the dorsal margin. The ventral margin of the facies articularis cranialis as seen in lateral norm is more projected caudally than the dorsal margin in the fossil and C. maguari, but is less projected in $M$. americana.

The overall morphology is more similar to that of Ciconia maguari than to Mycteria americana, but the 22 measures (Figure 4) taken from the fossil and recent vertebrae (Table 2) show some clear differences. The measures $a-d, k, q$ and $r$ in the fossil MCTFM-PV1090 stand out from both recent taxa, although the measures $q$ and $r$ (length of the vertebra) exhibit the larger range of variation among the recent specimens (Figure 5A). The measures $e-j, l$ and $m$ of the fossil fall within the upper range observed in the recent specimens. The measures $n, u$ and $v$ are within the range observed in C. maguari but larger than $M$. americana, whereas the measures $o$ and $p$ are equivalent to $C$. maguari but smaller than $M$. americana. The remaining measurements ( $s$ and $t$ ), of the fossil fall within the range observed in the vertebrae of $C$. maguari and $M$. americana. The dimensions of the fossil specimen are larger than the average values in the recent taxa, except in the measures $g, h, n, o$ and $p$, which are equivalent to $C$. maguari, and the measure $s$ which is the same for the three taxa (Figure 5B).

The morphometric differences in the fossil specimen could represent an allometric variation of Ciconia maguari, considering that ciconiids exhibit wide variations in size and 

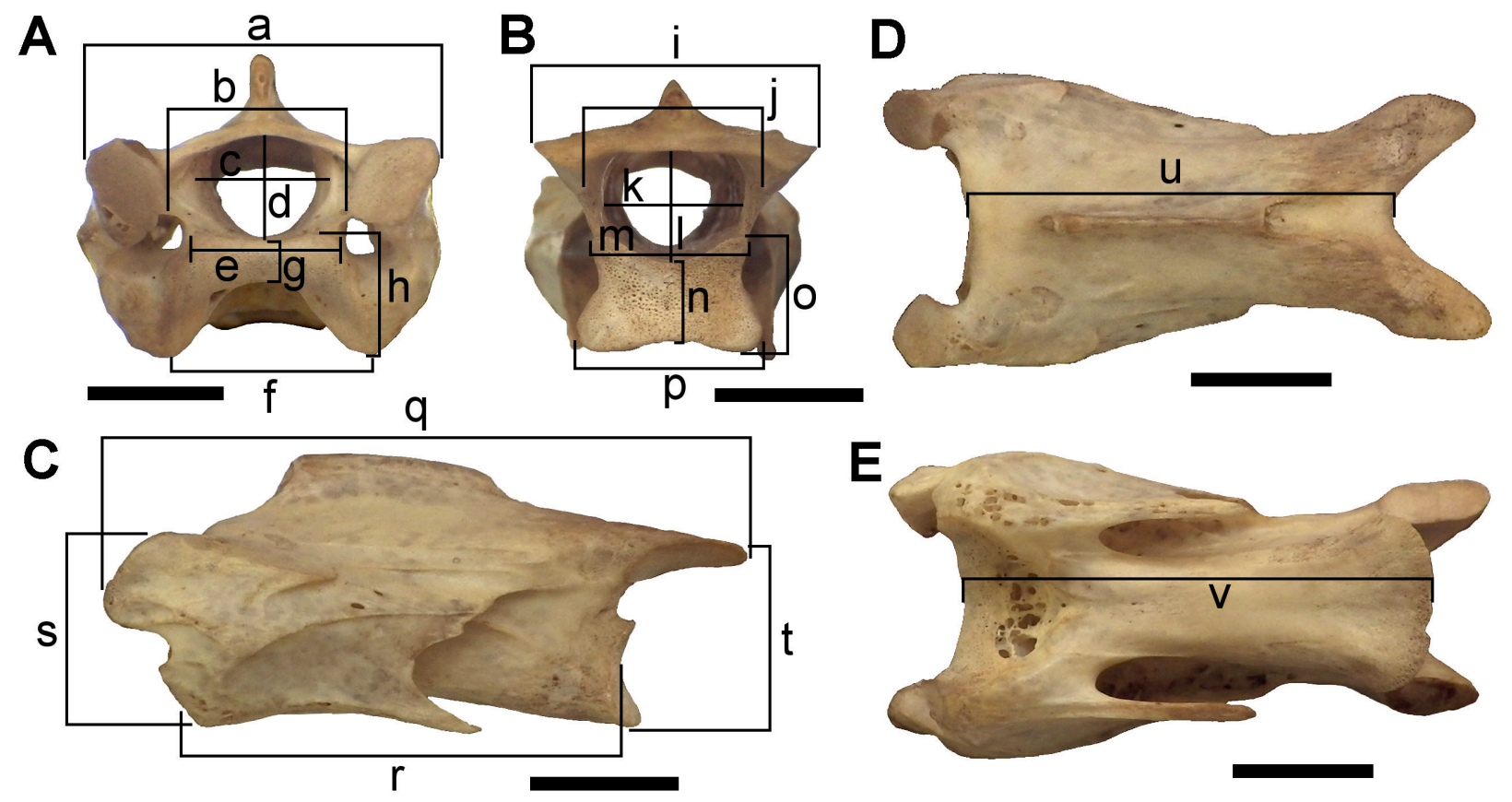

Figure 4. Recent vertebra of Ciconia maguari (specimen MCN-O0073) in cranial (A), caudal (B), left lateral (C), dorsal (D) and ventral (E) views, showing the measurements described in Table 2. Scale bars $=10 \mathrm{~mm}$.

morphology (Feduccia, 1967). Another possibility is that it belongs to an individual of the larger taxon C. lydekkeri Ameghino, 1891, a species recorded in Pleistocene deposits of Bolivia (Tarija Formation), Argentina (Luján Formation) and caves of Lagoa Santa in Brazil, and also in North America, considering that the species $C$. maltha found in that continent is now recognized a junior synonym of $C$. lydekkeri (Agnolín, 2009). In the absence of detailed published descriptions or specimens of cervical vertebrae of $C$. lydekkeri for comparison, and the lack of other fossil skeletal elements with diagnostic features from the same individual, the vertebra MCTFMPV1090 is regarded here as belonging to a large Ciconia sp.

\section{DISCUSSION}

The oldest fossils of ciconiids from South America known so far come from the upper Miocene-lower Pliocene Pisco Formation of Peru (Urbina \& Stucchi, 2005) and upper Miocene-Pliocene (Huayquerian Stage/Age) deposits of the Ituzaingó Formation exposed along the banks of Paraná River in the Entre Rios Province of northern Argentina, which includes fossils belonging to the genera Ciconia, Mycteria and Jabiru (Tambussi \& Noriega, 1996; Noriega \& Agnolín, 2008; Agnolín, 2009; Tambussi \& Degrange, 2013), besides one extinct marabou stork from the upper Miocene Puerto Madryn Formation, Chubut Province of Argentina (Noriega \& Cladera, 2008). Remains attributed to C. maguari were reported from sediments regarded as of upper Pleistocene (Lujanian Stage) in the provinces of Santiago de Estero (Cuello, 1988) and Buenos Aires (Pardiñas et al., 1996), but without detailed descriptions. Currently, Mycteria americana is the only stork found living to the north of Mexico (Olson, 1991), but fossils of Ciconia are found in deposits ranging in age from Miocene up to the Pleistocene (Rancholabrean, equivalent to the Lujanian Age) in North America, from where they migrated to the south prior to the GABI (Vuilleumer, 1985).

Ciconia maguari is a large (0.97-1.2 m tall) bird found in South American open (i.e. non-forested) lowlands east of the Andes, living in swamps, lakes, flooded pastures, reeds and rice fields, and southern Brazil (State of Rio Grande do Sul) harbours one of the largest populations (Elliott, 1992; Hancock et al., 1992). It is a common bird in the southern CPRS, and together with Mycteria americana, they are the only ciconiids found in this area (Bencke et al., 2010). Both species are common in shallow ( $<30 \mathrm{~cm}$-deep) natural wetlands such as swamps and lake margins and also in rice fields, where the highest abundance of $C$. maguari is reached during the phase of maximum flooding of the fields (Dias \& Burguer, 2005; Accordi \& Hartz, 2006). The presence of a fossil ciconiid in the SVF is important from a paleoenvironmental standpoint because this taxon is regarded as a good indicator of wetland environments, with its fossils being usually found together with aquatic taxa such as anatids and ardeids (e.g. Olson \& Rasmussen, 1986; Rasmussen et al., 1987; Noriega \& Agnolín, 2008; Diederle \& Noriega, 2013). Although sharing with C. maguari and M. americana the same wetlands in the CPRS, ardeids are also observed wading on the beach and ponds formed between coastal dunes, where ciconiids have not been observed so far by the authors and other researchers (Accordi \& Hartz, 2013), although the presence of C. maguari is reported from such environments (Elliott, 1992). This suggests that ciconiids have more restricted ecological tolerance, and therefore can be regarded as better environmental indicators than ardeids. 
Table 2. Description of the measures (shown in Figure 4) and values (in millimeters) taken from the fossil specimen MCTFM-PV1090 and recent specimens of Ciconia maguari and Mycteria americana.

\begin{tabular}{|c|c|c|c|c|c|c|c|c|c|c|c|c|}
\hline & & & \multicolumn{8}{|c|}{ Ciconia maguari } & \multicolumn{2}{|c|}{ Mycteria americana } \\
\hline \multirow{2}{*}{\multicolumn{2}{|c|}{ Measure }} & \multirow{2}{*}{$\begin{array}{l}\text { MCTFM } \\
\text { PV1090 } \\
\end{array}$} & \multicolumn{3}{|c|}{ MCN-SEMA } & \multicolumn{5}{|c|}{ MCT-PUC } & \multirow{2}{*}{$\frac{\text { MCN-SEMA }}{\text { O608 }}$} & \multirow{2}{*}{$\frac{\text { MCT-PUC }}{1832}$} \\
\hline & & & O0073 & O0281 & O0700 & 0574 & 0751 & 1448 & 1908 & 1910 & & \\
\hline $\mathrm{a}$ & $\begin{array}{l}\text { Width between } \\
\text { external margins of } \\
\text { the zygapophyses } \\
\text { craniales }\end{array}$ & 23 & 17 & 16.5 & 18 & 18.0 & 17.8 & 16.73 & 17.04 & 16.88 & 18.56 & 15.83 \\
\hline $\mathrm{b}$ & $\begin{array}{c}\text { Width between } \\
\text { internal margins of } \\
\text { the zygapophyses } \\
\text { craniales }\end{array}$ & 11.1 & 9 & 9 & 9 & 9.0 & 9.39 & 8.54 & 8.45 & 8.85 & 8.49 & 7.06 \\
\hline $\mathrm{c}$ & $\begin{array}{l}\text { Horizontal diameter } \\
\text { of the foramen } \\
\text { vertebrale at the } \\
\text { cranial end }\end{array}$ & 11 & 5.5 & 5.9 & 6 & 6.1 & 4.94 & 5.42 & 5.8 & 6.21 & 7.18 & 6.58 \\
\hline d & $\begin{array}{l}\text { Vertical diameter } \\
\text { of the foramen } \\
\text { vertebrale at the } \\
\text { cranial end }\end{array}$ & 6.7 & 5 & 5 & 5.5 & 5.3 & 6.57 & 5.05 & 5.04 & 5.3 & 4.78 & 4.33 \\
\hline $\mathrm{e}$ & $\begin{array}{l}\text { Dorsal width of the } \\
\text { facies articularis } \\
\text { cranialis }\end{array}$ & 8 & 6 & 8 & 7.1 & 7.1 & 6.1 & 6.45 & 6.48 & 6.35 & 7.84 & 6.03 \\
\hline$f$ & $\begin{array}{c}\text { Ventral width of the } \\
\text { facies articularis } \\
\text { cranialis }\end{array}$ & 11 & 10 & 10.5 & 9 & 10.9 & 8.56 & 9.48 & 10.71 & 9.97 & 10.85 & 8.52 \\
\hline $\mathrm{g}$ & $\begin{array}{l}\text { Height at the } \\
\text { middle of the facies } \\
\text { articularis cranialis }\end{array}$ & 2.5 & 2.1 & 2.1 & 2.1 & 2.7 & 1.99 & 2.05 & 2.6 & 2.19 & 1.71 & 1.35 \\
\hline $\mathrm{h}$ & $\begin{array}{l}\text { Height of the facies } \\
\text { articularis cranialis }\end{array}$ & 7.2 & 7 & 6.5 & 7 & 6.4 & 6.83 & 7 & 6.89 & 6.94 & 5.99 & 5.37 \\
\hline $\mathrm{i}$ & $\begin{array}{c}\text { Distance between } \\
\text { external margins of } \\
\text { the zygapophyses } \\
\text { caudales }\end{array}$ & 16.7 & 15 & 15.5 & 16.1 & 15.9 & 15 & 14.48 & 15.35 & 15.41 & 15.12 & 12.59 \\
\hline $\mathrm{j}$ & $\begin{array}{c}\text { Distance between } \\
\text { internal margins of } \\
\text { the zygapophyses } \\
\text { caudales }\end{array}$ & 10.3 & 9.5 & 10 & 10.9 & 9.4 & 8.58 & 8.05 & 9.26 & 9.13 & 7.56 & 6.43 \\
\hline $\mathrm{k}$ & $\begin{array}{l}\text { Horizontal diameter } \\
\text { of the foramen } \\
\text { vertebrale at the } \\
\text { caudal end }\end{array}$ & 9.4 & 7.9 & 8 & 9 & 7.9 & 7.53 & 7.21 & 7.77 & 7.95 & 7.16 & 4.75 \\
\hline 1 & $\begin{array}{l}\text { Vertical diameter } \\
\text { of the foramen } \\
\text { vertebrale at the } \\
\text { caudal end }\end{array}$ & 7.5 & 6 & 6 & 6.8 & 6.2 & 5.78 & 6.28 & 5.51 & 6.12 & 5.74 & 5.5 \\
\hline $\mathrm{m}$ & $\begin{array}{c}\text { Dorsal width of the } \\
\text { facies articularis } \\
\text { caudalis }\end{array}$ & 9.4 & 8.4 & 8.1 & 8.4 & 8.8 & 7.92 & 7.91 & 8.02 & 8.62 & 7.53 & 7.21 \\
\hline $\mathrm{n}$ & $\begin{array}{l}\text { Ventral width of the } \\
\text { facies articularis } \\
\text { caudalis }\end{array}$ & 10.8 & 10 & 10 & 10.5 & 11.6 & 9.26 & 9.8 & 10.03 & 10.85 & 3.41 & 3 \\
\hline o & $\begin{array}{l}\text { Height at the } \\
\text { middle of the facies } \\
\text { articularis caudalis }\end{array}$ & 3.4 & 4.5 & 4.1 & 4 & 4.6 & 3.96 & 4.12 & 3.77 & 4.28 & 5.63 & 5.29 \\
\hline $\mathrm{p}$ & $\begin{array}{l}\text { Width of the facies } \\
\text { articularis caudalis }\end{array}$ & 5.8 & 6 & 6 & 6 & 6.1 & 5.32 & 5.43 & 5.82 & 5.99 & 11.8 & 9.24 \\
\hline
\end{tabular}


Table 2. Cont.

\begin{tabular}{|c|c|c|c|c|c|c|c|c|c|c|c|c|}
\hline & & \multirow{3}{*}{$\begin{array}{l}\text { MCTFM } \\
\text { PV1090 }\end{array}$} & \multicolumn{8}{|c|}{ Ciconia maguari } & \multicolumn{2}{|c|}{ Mycteria americana } \\
\hline \multirow{2}{*}{\multicolumn{2}{|c|}{ Measure }} & & \multicolumn{3}{|c|}{ MCN-SEMA } & \multicolumn{5}{|c|}{ MCT-PUC } & \multirow{2}{*}{$\frac{\text { MCN-SEMA }}{\mathrm{O} 608}$} & \multirow{2}{*}{$\frac{\text { MCT-PUC }}{1832}$} \\
\hline & & & $\mathrm{O} 0073$ & O0281 & O0700 & 0574 & 0751 & 1448 & 1908 & 1910 & & \\
\hline q & $\begin{array}{l}\text { Length between } \\
\text { zygapophyses } \\
\text { craniales and } \\
\text { caudales }\end{array}$ & 42.4 & 37 & 36 & 36.5 & 38.4 & 33.1 & 34.51 & 34.05 & 38.05 & 30.07 & 25.44 \\
\hline $\mathrm{r}$ & $\begin{array}{l}\text { Length between } \\
\text { facies articularis } \\
\text { craniales and } \\
\text { caudales }\end{array}$ & 31.5 & 26.2 & 26 & 26 & 28.6 & 23.9 & 24.7 & 26.55 & 27.65 & 20.49 & 18.72 \\
\hline $\mathrm{s}$ & $\begin{array}{l}\text { Height at the cranial } \\
\text { end of the vertebra }\end{array}$ & 11.6 & 11 & 11 & 11.5 & 11.0 & 12.1 & 10.99 & 12.22 & 12.49 & 12.66 & 10.88 \\
\hline $\mathrm{t}$ & $\begin{array}{l}\text { Height at the caudal } \\
\text { end of the vertebra }\end{array}$ & 13.6 & 11.9 & 11.5 & 12 & 12.2 & 11.3 & 11.69 & 11.43 & 12.56 & 13.96 & 10.56 \\
\hline $\mathrm{u}$ & $\begin{array}{l}\text { Length of the lamina } \\
\text { dorsalis arcus }\end{array}$ & 29 & 29.78 & 27.24 & 29.91 & 26.8 & 22.4 & 22.86 & 23.29 & 26.14 & 20.67 & 17.8 \\
\hline $\mathrm{v}$ & $\begin{array}{c}\text { Lenght of the corpus } \\
\text { vertebrae }\end{array}$ & 32.1 & 33.91 & 32.89 & 33.5 & 29.9 & 24.5 & 26.93 & 27.57 & 29.25 & 21.43 & 19.46 \\
\hline
\end{tabular}
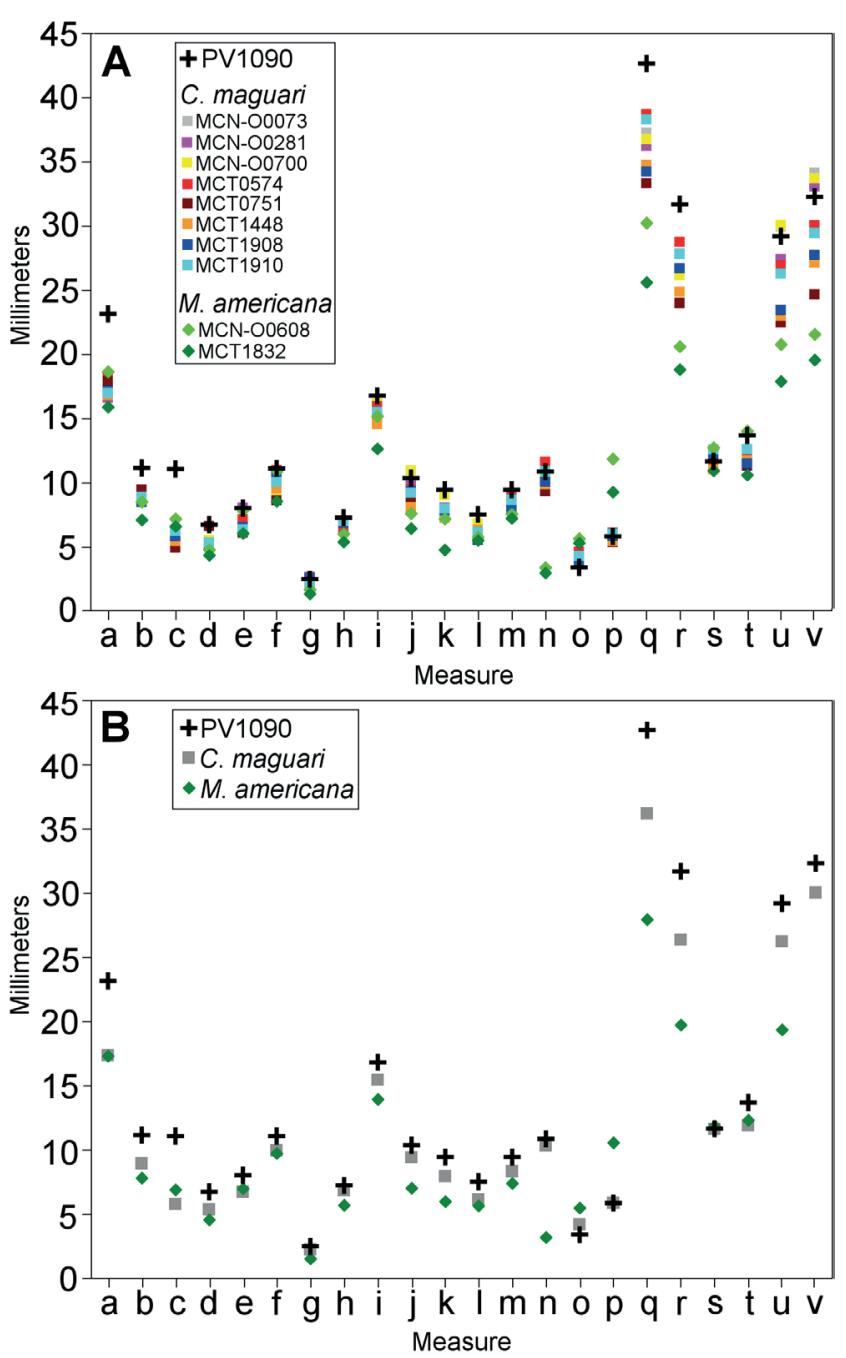

Figure 5. Comparison between the total (A) and average (B) measures of the recent specimens of Ciconia maguari, Mycteria americana and the specimen MCTFM-PV1090.
Although not common as other vertebrates, remains of birds are relatively abundant in the fossil record, with gregarious taxa with large populations such as penguins being better represented (Olson, 1985; Tambussi \& Degrange, 2013), but most of the ecological and environmental information from avian fossil assemblages is lost because of the inevitable post mortem destruction of the bones (Behrensmeyer et al., 2003). The presence in the SVF of a bird with well-known ecological requirements preserved within defined depositional and stratigraphic settings, allows obtaining information also from the taphonomic features on the fossil and from the sedimentological aspects of the fossilbearing deposit, thus providing tools for a better understanding of the paleoenvironment at the time of its deposition.

\section{Taphonomy}

Ecological aspects such as feeding and escape behavior influence the size and robustness of certain skeletal elements, thus resulting in preservation bias toward these elements (Livingston, 1989). Because bones with high surface-tovolume ratios such as vertebrae are more easily destroyed by sedimentary processes, the axial skeleton of birds is in general under-represented compared to the anterior and posterior extremities, but better represented than cranial elements in modern bird assemblages (Rich, 1980; Erickson, 1987; Livingston, 1989; Cruz, 2005). As a result, most of the works dealing with taphonomic aspects of birds describe features of the long and robust bones such as humeri, tibiotarsi and tarsometatarsi (e.g. Rich, 1980; Livingston, 1989; Behrensmeyer et al., 2003). Because the cervical vertebra described here is relatively well-preserved and associated with fossils with different preservation features, it opens an opportunity to explore aspects of the taphonomy of this particular skeletal element. 
Several studies have demonstrated that body size exerts a strong control on the preservation of fossils of birds, usually by increasing resistance to weathering and mechanical destruction (Behrensmeyer et al., 2003; Mitchell, 2015). Bones exposed at the air-sediment interface develop weathering stage (WS) 1 features (surface cracks) in relatively short time, followed by flaking of the bone (WS2) (Behrensmeyer, 1975; 1978), but the timing and intensity of weathering seems to be influenced by climate (Gardner et al., 2016), thus those patterns can vary through time in response to climate oscillations. Although the process of weathering is similar in bones of mammals and birds, the latter seems to develop surface cracks and flaking (corresponding to WS1 and WS2) simultaneously between 0 and 1 year of exposure time, which results in quick destruction and the scarcity of bones of WS $>1$ in assemblages (Behrensmeyer et al., 2003). The assemblage described here includes elements with WS1 features (see Figures $2 \mathrm{~F}-\mathrm{G}$ ), which were exposed on the surface of the surrounding area prior to being buried, together with unweathered bones such as the vertebra and osteoderms. The absence of weathering features in the vertebra MCTFMPV1090 thus indicates that it was not subaerially exposed (or exposed very briefly) prior to burial, and was incorporated to the depositional environment in relatively short time after death and disarticulation. Two possible scenarios that could account for the protection from weathering between decomposition, disarticulation, transport and burial would be: (i) the vertebra being protected by soft tissue, or (ii) the total or partial submersion of the dead carcass.

The preservation potential of bird bones is also related to the type of environment they live in. Wetlands, lakes and marine environments exhibit the highest preservation potential of fossils of birds; in fact, aquatic birds are better represented in the fossil record than fully terrestrial species (Rich, 1980; Mitchell, 2015). In samplings of recent bones made along transects in Amboseli Park, in Kenya, Behrensmeyer et al. (2003) found a low proportion of aquatic birds, concluding that this was because the transects did not reach close to aquatic environments. Being from a taxon with aquatic habits, the good preservation of the specimen MCTFM-PV1090 was probably favored by its direct association in life with a depositional environment that enhanced the preservation potential, and also by reducing the time and distance of transport to the burial site. Besides, the sedimentological analysis of the deposit (see Sedimentology below) suggests that its burial was relatively quick because of climate-driven increased runoff and sediment deposition.

The assemblage associated with the bird vertebra is a mixture of fossils of different species with distinct states of preservation, which suggests that it is composed of remains of different sources with varying taphonomic histories (Behrensmeyer, 1982), therefore can be classified as a Model III fossil assemblage of Johnson (1960). Fossilized bones break more easily than fresh ones (Fernández-Jalvo \& Andrews, 2003), thus the fragmented remains in the assemblage probably consist of fossils reworked by erosion of pre-existing deposits. Some fossils (including the bird vertebra and osteoderms) do dot exhibit extensive signs of abrasion despite being broken, as indicated by the sharp broken edges and unabraded irregular surfaces, whereas others exhibit signs of abrasion (such as the one in Figure 2E), the latter having been probably subject to several episodes of exhumationtransport-burial. Although this mixing could indicate elements that were transported by flowing water for variable distances from source areas up to the burial site, the abrasion in general points to intense transport, although not necessarily for longer distances (Aslan \& Behrensmeyer, 1996), then the mixture of abraded and unabraded bones could indicate that these remains were subject to different flow regimes (velocity of the water current).

The fossils encompass the three groups recognized by Voorhies (1969), characterized by skeletal elements with distinct shapes and densities, and thus are subject to differential transport. Elements of Group I are moved by water with lower fluid shear stress, whereas the elements of Groups II and III require progressively higher current velocities to be moved, which affects the representativity of skeletal elements in fossil assemblages (Voorhies, 1969; Behrensmeyer, 1975). The association of the bird vertebra and other elements of the Group I of Voorhies (1969) with skeletal elements more dense and with different shapes of the Groups II and III suggest deposition by currents with variable velocities, possibly related to increased-decreased flow controlled by seasonal cycles or long-term climatic changes.

Experiments with skeletons of three species of birds put in cages on a stream floodplain showed that most of the disarticulation of the vertebrae took place between 15 and 45 days and was complete after 60 days; cervical vertebrae were totally disarticulated from each other between 21 and 40 days (Bickart, 1984). Davis \& Briggs (1998) observed that in swamp and coastal embayment the disarticulation of the skeleton of birds followed a sequence that allowed recognizing distinct stages. Regarding the axial skeleton, the skull and cervical vertebrae disarticulated first (Stage 3a), whereas the other vertebral segments disarticulated later. Although the process of disarticulation depends on the size, morphology and depositional setting (Hill, 1980), it is more intense in environments with stronger flow, whereas low energy environments favor the preservation of articulated carcasses (Davis \& Briggs, 1998; Dyke \& Lindow, 2009). The isolated vertebra MCTFM-PV1090 was probably removed from the carcass located upstream shortly after disarticulation.

The fossils in the assemblage are relatively small $(>20$ $\mathrm{cm}$ ), which seems to indicate selection by size during transport. Bones with volumes $<1,000 \mathrm{cc}$ are easily moved and transported even by currents with relatively slow velocities of 10 to $150 \mathrm{~cm} / \mathrm{s}$ (Behrensmeyer, 1975). Although the results of Voorhies (1969) were obtained from mammalian bones, experimental data show that avian vertebrae behave in a similar way, being more easily dispersed than other bones of the skeleton once disarticulation has taken place (Coard \& Dennell, 1995; Trapani, 1998). The good preservation of the vertebra MCTFM-PV1090 indicates that the water flow was strong enough to separate it from the carcass and transport 
it for some distance up to the burial site, but the lack of extensive mechanical destruction as observed in other fossils from the assemblage suggests either a moderate to weak current or transportation for a short period/distance up to the burial site. Weak currents could also explain the apparent absence of other avian remains in the assemblage, because in fluvial settings with low-energy flow remove the more transportable bones such as vertebrae (Group I of Voorhies, 1969), resulting in winnowed fossil assemblages dominated by elements of the groups II and III (Behrensmeyer, 1991; Aslan \& Behrensmeyer, 1996).

The shape is also a major factor influencing the transport of bone remains, capable of increasing or decreasing by $15 \%$ the settling speed of a skeletal element (Behrensmeyer, 1975). Bones with irregular shapes have larger surfaces, which increases the potential for transport (Coard \& Dennell, 1995). Vertebrae exhibit large surfaces for their volume because of the processes and large foramina, which increases transportability, and can be moved by rolling and tumbling for long distances until being buried (Trapani, 1998). In smooth bottoms of fine sand or mud the flowing water is characterized by a thin, slow sub-layer separating the bottom surface from the faster-moving turbulent layer above; any bone that projects above the thickness of the sub-layer is prone to be moved by the turbulent layer (Behrensmeyer, 1975; Hanson, 1980). The large surface-to-volume relationship of the vertebra MCTFMPV1090 probably facilitated its entrainment by turbulent flow, at least for short distances, and the fragmentation would have been the result of impacts with the bottom during transport.

The fragmented areas in the vertebra MCTFM-PV1090 are found in structures located around its longitudinal axis, such as the processus spinosus, laminae arcocostales and zygapophyses craniales, which suggest that it was transported with the longer axis oriented perpendicular to the direction of the water flow, in a manner similar to small symmetrical bones such as metatarsi (Hanson, 1980). The cranial end exhibits more extensive breaking than the caudal end, which is broken only on the edges of the zygapophyses caudales and facies articularis caudalis (Figure 3 ).

The distribution of broken areas could be related to the structural difference between the cranial and caudal ends of the vertebra. In order to better understand how this could have affected its transport and resulting breakage, the vertebra was classified according to the particle shape model of Zingg (1935) by measuring its longest (a), intermediate (b) and shorter (c) axes, perpendicular to each other. In the cranial end, however, the b-axis is longer and the c-axis is shorter compared to the caudal end, whose axes are almost of the same length, resulting in an elliptical-shaped cranial end (Figure 6A) and an almost circular caudal end (Figure 6B). Because of this difference, in the scheme of Zingg (1935) and modified by Krumbein (1941a) the vertebra as measured from the cranial end is classified as blade-shaped, whereas the caudal dimensions result in a rod-like shape (Figure 6C), therefore the overall geometric shape of the vertebra is a cone with elliptical base and subcircular apex (Figure 6D). This implies that as the current moved the vertebra it probably rotated around its longer axis tumbling in an irregular manner rather than rolled uniformly as a cylindrical body, which would have distributed the breaking and abrasion more evenly (see for example the fig. 8 in Lopes \& Ferigolo, 2015).

The concentration of broken areas around the cranial end (Figure 3) can be related to its larger radius, because although both ends were connected and rotated around the same axis, the cranial end would describe a larger orbit at faster angular rates, thus striking the bottom surface with higher force as the vertebra was moved. This phenomenon, which has become known as 'Aristotle's wheel paradox', is suggested in the book Mechanica, attributed to Aristotle, as the process responsible for making elongated pebbles become rounded (Hett, 1955). In the Problem 15 of the Mechanica, it is stated "Why are the stones on the seashore, which are called pebbles round, when they are originally made from long stones and shells? Surely it is because in movement what is further from the middle moves more rapidly. For the middle is the centre, and the distance from it the radius. And from an equal movement the greater radius describes a greater circle. But that which travels a greater distance in an equal time describes a greater circle. Things traveling with a greater velocity over a greater distance strike harder; (...) So that the parts further from the middle must always get worn down." (Hett, 1955; p. 369 371). In fact, such statement is consistent with observation and experimental data, which shows that the rate of rounding and wearing is larger in angular and larger particles than in smaller and more rounded ones (Daubrée, 1879; Wentworth, 1919; Krumbein, 1941b).

The lighter skeletal elements moved by rolling and tumbling are transported at greater speeds because the energy is not dissipated by friction with the bottom, which is the case with heavier bones (Hanson, 1980). The presence of sharp edges on the broken portions and lack of extensive abrasion in the fossil vertebra seems consistent with transport by short-term suspension and multiple impacts with the bottom. Large bones become abraded by friction with the underlying sediment, but those small and/or with large surfaces for their volume can be transported by suspension intermittently, depending on the fluid velocity, thus reducing friction with the bottom and consequent abrasion (Fernández-Jalvo \& Andrews, 2003).

\section{Sedimentology}

The taphonomic features of the vertebra MCTFMPV1090 show that its preservation was related to autogenic factors (size, shape, density, surface-to-volume ratio), but allogenic factors such as the type of habitat, depositional environment and climate also affected its preservation. Whereas the autogenic factors deduced from the morphology, systematics and ecology, the allogenic ones are inferred from the sedimentary characteristics of the deposit.

The absence of taphonomic features that indicate transport for long distance and/or time shows that after decomposition the vertebra was disarticulated and removed from the skeleton, but preserved in or very close the same environment the bird lived in, and was buried together with mammalian fossils transported from surrounding areas or reworked from older 
A

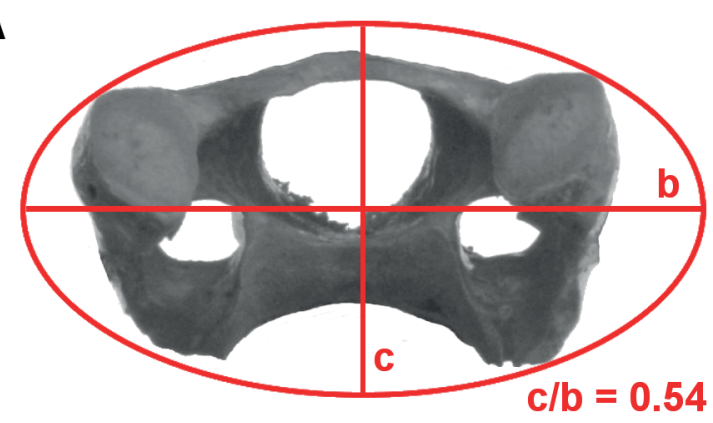

C

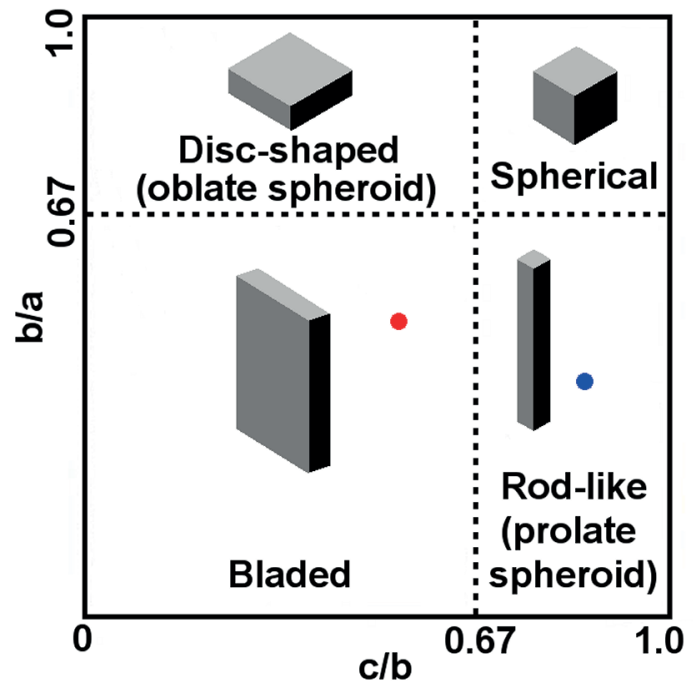

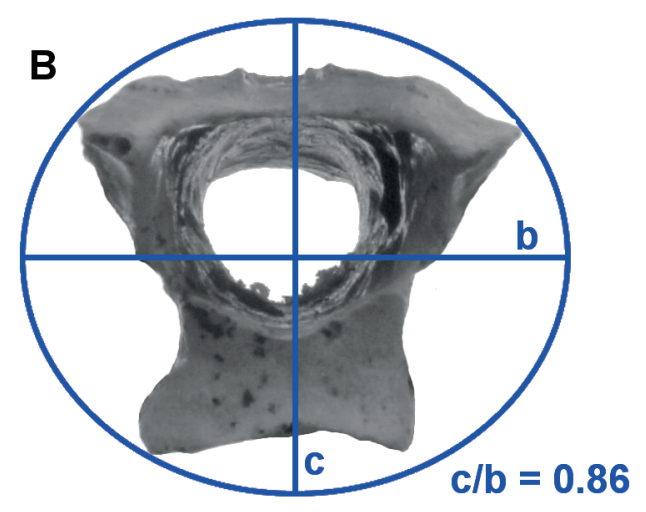

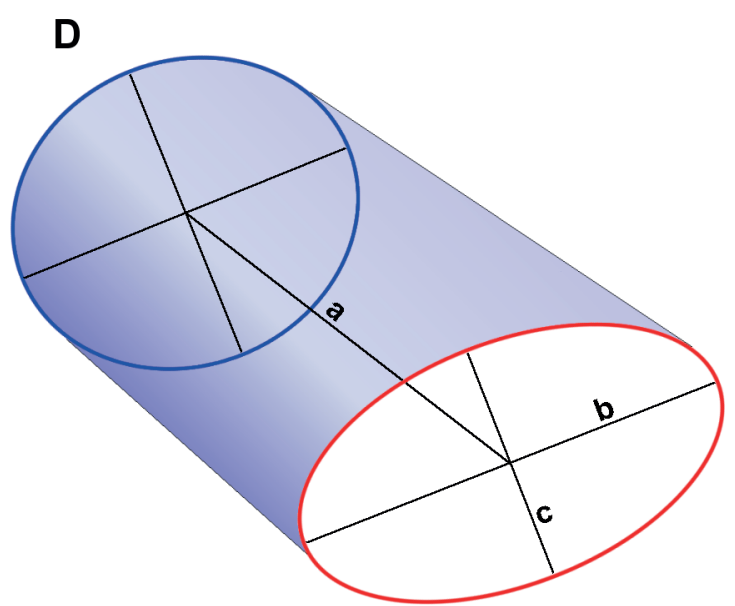

Figure 6. Shapes of the cranial (A) and caudal (B) ends of the fossil vertebra MCTFM-PV1090, based on the proportion between the b and c axes outlined. C, classification of the shape of the vertebra according to Zingg (1935, modified by Krumbein, 1941a) considering the cranial (in red) and caudal (blue) b/c proportions (adapted from Pettijohn, 1957). D, geometric shape of the vertebra.

deposits. If the vertebra was much older (i.e. reworked from preexisting deposits) or transported for longer distances up to the burial site, it probably would have been destroyed by mechanical processes, as seems to be the case of most fossils of mammals found in the SVF (Lopes \& Ferigolo, 2015). The mixing of fossils with varying taphonomic features in the assemblage, presence of mudclasts and the erosive base of the facies F2 indicate deposition by flowing water, which points to a period of increased precipitation, because after the Barrier II (Figure 1) was formed in the middle Pleistocene (Lopes et al., 2014a,b), all fluvial discharge coming from the hinterland to the coast was interrupted. From then on, rainfall has been the only source of water to streams and wetlands developed on the Lagoon System III, located seaward of that barrier. In fact, wetter climates characterized by increased runoff and sedimentation seem to be better for the preservation of avian remains than dry climates (Gardner et al., 2016).

Although it is not clear yet if the facies F1 was deposited in a floodplain as suggested above, its yellow color and presence of iron oxide nodules and clay indicates weathering and incipient pedogenesis, thus pointing to subaerial exposure prior to the deposition of the facies F2 on top of it. The channel filled with plant-derived organic-rich sand located nearby at a lower stratigraphic position than F2 (Figure 2C), seems to have been deposited in low energy setting as an abandoned meander or oxbow lake, but the facies F2 and its associated fossils was deposited in a different setting, under conditions of relatively high discharge and high bed, load which commonly results in shallow and wide channels (Behrensmeyer \& Hook, 1992; Aslan \& Behrensmeyer, 1996; Miall, 2006). Because of the dependence of rainwater, the depositional environment of F2 was probably similar to the ephemeral braided streams (washouts) formed today on the beach face of the CPRS during the rainy seasons, characterized by a wide, shallow semi-confined main channel divided in smaller channels by longitudinal sand bars formed due to the high sediment load eroded from the banks (Figure 7).

The masses of iron-manganese, on the other hand, would have been precipitated during episodes of decreased water flow, because such masses are redoximorphic features accumulated in poorly drained (waterlogged) soils that indicate anaerobic conditions related to high water table (Evans, 1992; D'Amore et al., 2004; Vepraskas, 2015; Soil Science Division Staff, 2017). The masses found within F2 are unconsolidated aggregates of sand grains stained black to reddish by precipitation of dissolved manganese and iron oxides, as indicated by the analysis of similar nodules found in the overlying CF (Lopes et al., 2016a). The formation of Fe- 


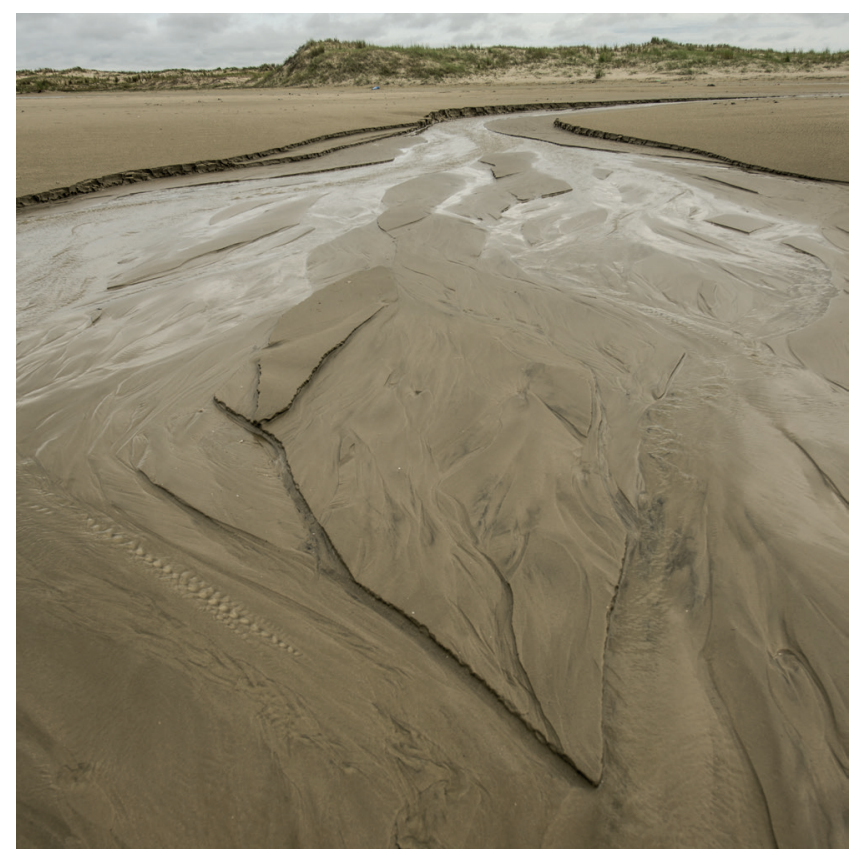

Figure 7. Ephemeral stream formed on the beach face in the southern CPRS during a rainy season. The vertebra MCTFM-PV1090 and associated fossils seem to have been preserved in a similar depositional environment (photo by R.P. Lopes).

Mn masses is strongly controlled by precipitation and indicate warm to moderate temperatures in subtropical climate, and precede the formation of nodules of iron-manganese oxides, which require relative high precipitation and some 3,000 to 4,000 years of pedogenesis to develop (Golden et al., 1988; Stiles et al., 2001).

The dispersed iron-manganese masses point to periodic oscillations of the water table, possibly seasonal floodingdrying cycles, but the masses accumulated in discrete levels at the top (Figure 2B) and within (Figure 2D) the facies F2 suggest periods of stabilization, creating redoximorphic horizons. Waterlogged soils usually exhibit gray-bluish colors' because of reducing conditions (Birkeland, 1974; Vepraskas, 2015), but the yellow hue of F2 suggests post-depositional weathering and re-oxidation of reduced iron into goethite under aerobic conditions (Davey et al., 1975; Schwertmann, 1993) related to high evaporation and/or lowering of the water table. The pink color (7.5YR 7/3) of the vertebra MCTFMPV1090 probably reflects the incorporation of iron oxides during diagenesis, as indicated by electron dispersive X-ray spectroscopy (EDS) analysis of other fossils found in the SVF (Lopes \& Ferigolo, 2015). Considering that the depositional systems of the CPRS consist essentially of quartz sand with small amounts of other accessory minerals, the iron oxide and clay found in the upper F2 are secondary materials, produced by incipient pedogenesis and weathering of the heavy and less stable minerals such as feldspars (Birkeland, 1992; Evans, 1992), as observed in the Pleistocene barriers (Villwock \& Tomazelli, 1995). This indicates the cessation of water flow and lowering of the water table under drier conditions, related to long-term climate change.

\section{Paleoclimatic implications}

The physical features observed in the facies F2 suggest that around $38 \mathrm{ka} \mathrm{b} 2 \mathrm{k}$ the climate in the study area was seasonal, wet and relatively warm, with permanent to semipermanent water bodies, suitable for aquatic birds such as ciconiids. That interval corresponds to the marine isotope stage (MIS) 3, spanning between 57 to 29 ka b2k (Lisiecky \& Raymo, 2005). MIS 3 is a climatic stage regarded as an interstadial due to the wetter and warmer climate relative to the preceding stadial MIS 4 and the following stadial MIS 2, as shown by paleotemperature reconstructions from ice cores (Figure 8). In southern South America that interstadial was characterized by increased fluvial processes, stabilization of eolian deposits, soil formation and changes in the distribution of terrestrial vertebrates (Blasi et al., 2010; Brunetto et al., 2015; Gasparini et al., 2016; Ubilla \& Martínez, 2016).

Variations of the environmental factors, especially flood-drought cycles, are an important factor controlling the distribution of waterbirds (Gimenes \& Anjos, 2006; Almeida et al., 2016). The avian families with living representatives found in Pleistocene deposits can be better for paleoenvironmental reconstructions than mammals, which in most cases do not have living representatives (Tambussi $\&$ Noriega, 1996). The presence of a stork suggests that environmental conditions were similar to the present ones in the southern CPRS around $38 \mathrm{ka} \mathrm{b} 2 \mathrm{k}$. In fact, isotope analyses in fossil mammals with ages ranging between 30 and $50 \mathrm{ka}$ (Lopes et al., 2013) indicate that the landscape of the southern CPRS during MIS 3 would have been similar to that of today, with wetlands surrounded by grasslands and sparse trees and bushes.

The distribution of bird species in North America during the Pleistocene exhibit climate-driven shifts (Holmes, 1912; Emslie, 1998), indicating that long-term climate changes such as glacial-interglacial cycles, but probably also millenialscale oscillations such as Heinrich Stadials (HS), DansgaardOeschger (D-O) oscillations and Antarctic Isotopic Maxima (AIM), promoted environmental changes that affected the distribution and abundance of the avifauna. It is likely that such changes are also represented in the fossil avifauna of South America. As examples, the presence in deposits of the Sopas Formation in northern Uruguay of fossils of the Magellan goose Chloephaga picta (Gmelin, 1789) that today lives only to the south of $35^{\circ} \mathrm{S}$, indicates a latitudinal shift of the cold and seasonal climate during the Late Pleistocene (Tambussi et al., 2005). In Argentina, a diverse fossil avifauna dated as of 37.8 $\pm 2.3 \mathrm{ka}$, essentially the same age of the sediment associated with the vertebra MCTFM-PV1090, was described from the La Chumbiada Member of the Luján Formation (Cenizo et al., 2015). That avifauna includes a great proportion of aquatic birds, mollusks and rodents, thus indicating that wet environments were widespread through the Pampas from southern Brazil to northeastern Argentina around $38 \mathrm{ka} \mathrm{b} 2 \mathrm{k}$.

The age of $37.9 \mathrm{ka}$ coincides with the later part of the AIM 8 (Figure 8), a warmer period in Antarctica that was correlated to a cooling of the Northern Hemisphere, which resulted in southward displacement of the intertropical 


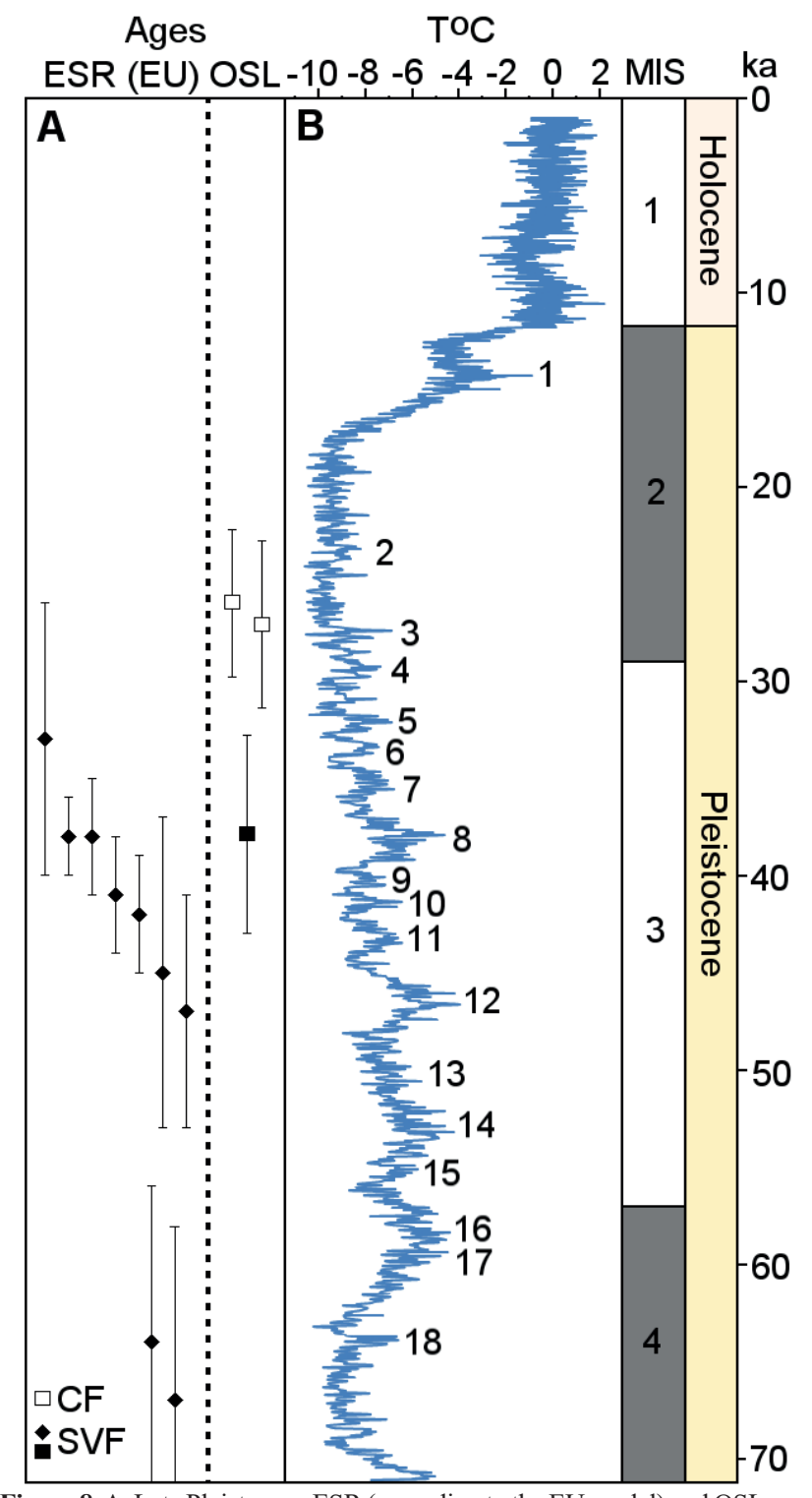

Figure 8. A, Late Pleistocene ESR (according to the EU model) and OSL ages obtained from fossils and sediments of the Santa Vitória Formation (SVF) and Cordão Formation (CF); the OSL age associated with the vertebra is shown by the black square. $\mathbf{B}$, temperature variations relative to the present recorded in the EPICA Dome C ice core (Jouzel et al., 2007); the numbers indicate the warm Antarctic Isotope Maxima (AIM); the event AIM 8 is chronocorrelated to the age of the fossil-bearing deposit described here. Marine Isotope Stage (MIS) boundaries according to Lisiecki \& Raymo (2005).

convergence zone (ITCZ), thus increasing precipitation in the Southern Hemisphere (EPICA Community Members, 2006; Jouzel et al., 2007; Wolff et al., 2009; Lemieux-Dudon et al., 2010; Brook \& Buizert, 2018). Although such millennialscale climate oscillations were identified from oxygen and deuterium isotopes in ice cores, the depositional setting and fossil assemblages of similar age containing bird taxa that indicate wetter conditions show that such oscillations may also be represented in sedimentary and fossil continental records in lower latitudes.

The influence of the Pleistocene climate cycles on the range of distribution of bird species could also have been negative, by reducing the area of suitable habitats for certain taxa, especially waterbirds. In southern South America, it is likely that wetland areas were reduced in area during glacial stages because of the northward expansion of arid and semiarid environments (mean annual precipitation $\leq 500$ $\mathrm{mm}$ ) driven by latitudinal shifts cold and dry climate belt (Clapperton, 1993; Iriondo, 1999).

The ciconiid described here, together with all the largeand megamammals and other wetland-dwelling species such as Myocastor coypus Molina, 1822 and Holochilus brasiliensis (Desmarest, 1819) (Pereira et al., 2012; Kerber et al., 2012) found in the SVF, are so far absent in the overlying loess deposits of the CF, deposited between $\sim 30$ and $10 \mathrm{ka}$ b2k (Lopes et al., 2016a). If this disappearance is real and not just preservation or collecting bias, it would indicate that the environment in the southern CPRS during the last glacial (MIS 2), between 29 and $11.7 \mathrm{ka} \mathrm{b2k}$, was inadequate for aquatic birds as well as for mammals. Considering that Ciconia maguari is found living as far as southern Argentina (Elliott, 1992; Hancock et al., 1992), low temperatures at that time apparently would not have been a problem for ciconiids, but the expansion of dry environments would have been a major factor that reduced their distribution. The negative effect of the climate during the last glacial seem to be also indicated by the avian fossil record of Argentina, where the portion of the Lujanian Age corresponding to the last glacial was marked by a decrease in the percentage of first records of families and genera compared to the preceding Bonaeran Age (Tambussi et al., 1993). After disappearing from the southern CPRS during the last glacial ciconiids would have returned during the Early-Middle Holocene, as the climatic amelioration led to the expansion of wetlands. Radiocarbondated organic-rich sediments indicate that by around $10 \mathrm{ka}$ BP climate became wet and warm in the region (Lima et al., 2013; Caron, 2014), also indicated by the accumulation of frustules of freshwater diatoms in the uppermost CF (Lopes et al., 2016b). Archaeological sites of $\sim 5$ ka found in the County of Santa Vitória do Palmar (Schmitz et al., 1997) contain remains of aquatic mammals that include $M$. coypus and $H$. brasiliensis, plus the marsh deer (Blastocerus dichotomus Wagner, 1844) and the anatid Netta peposaca (Vieillot, 1816).

If the ciconiid described here was an individual of Ciconia lydekkeri, then its disappearance from southern Brazil during the last glaciation was not local, but part of a continental-scale extinction, because that species disappeared from South and North America during the Late Pleistocene (Emslie, 1998; Tyrberg, 2008). Being a larger species than C. maguari, it is possible to speculate whether its large size could have been a factor in the extinction, as proposed by Miller (1912). On the other hand, if the specimen MCTFM-PV1090 represents a morphotype of $C$. maguari, then it shows that this species had its distribution restricted to suitable areas (refugia) until the wet and warm climate during the Holocene allowed for its return to the CPRS. In either case, if the presence of ciconiids at distinct times in the CPRS was in fact intermittent rather than a preservation bias, it would indicate that the distribution and diversity of the avifauna in southern Brazil have oscillated 
during the late Quaternary in response to climate-driven environmental changes, similarly to what has been inferred for the mastofauna. However, additional fossils are needed in order to test this hypothesis.

\section{CONCLUSIONS}

The vertebra MCTFM-PV1090 described here is the first avian remain identified in the fossiliferous deposits of the Santa Vitória Formation, and indicates the presence of a large ciconiid, either a morphotype of Ciconia maguari or another species such as C. lydekkeri, in this region around $37.9 \mathrm{ka} \mathrm{b} 2 \mathrm{k}$, which corresponds to the interstadial MIS 3, as indicated by the age obtained from the fossil-bearing sediment. This fossil record is relevant because indicates the presence of aquatic environments at that time, consistent with other fossil and geological records throughout southern South America, which show that MIS 3 was characterized by wet and relatively warm climate.

The association of a ciconiid bird with mammalian remains of distinct shapes and sizes in a sedimentary matrix exhibiting redoximorphic and oxidizing features indicates deposition by flowing water with high sediment load, apparently subject to oscillations of the discharge and water table related to seasonal climate.

The preservation of the fossil was controlled by a combination of autogenic (morphological) and allogenic (environmental and depositional) features. Its large size and association with aquatic habitat probably favored its preservation, by ensuring its burial in a relatively short time after decomposition and disarticulation. The major taphonomic modifications on the specimen seem to result of its behavior under flowing water related to its shape, which caused it to be moved with the long axis perpendicular to the flow direction, tumbling because the geometric difference between its cranial and distal ends.

\section{ACKNOWLEDGEMENTS}

The authors thank to C. Suertegaray (Museu de Ciências e Tecnologia-PUC) and G. Bencke (Museu de Ciências Naturais/SEMA) for access to specimens from the osteological collections under their care, and to O.A.R. Silva, from Universidade Estadual de Tocantins (UNITINS) for his help with the anatomical terms in Latin.

\section{REFERENCES}

Accordi, I.A. \& Hartz, S.M. 2006. Distribuição espacial e sazonal da avifauna em uma área úmida costeira do sul do Brasil. Revista Brasileira de Ornitologia, 14:117-135.

Accordi, I.A. \& Hartz, S.M. 2013. Aves em um mosaico de ambientes costeiros no sul do Brasil. Atualidades Ornitológicas On-line, 172:49-59.

Agnolín, F.L. 2009. El registro fósil de Ciconia lydekkeri Ameghino, 1891 en el Pleistoceno de Sudamérica. Studia Geologica Salmanticensia, 45:53-58.
Aires, A.A.S. \& Lopes, R.P. 2012. Representativity of Quaternary mammals from the southern Brazilian continental shelf. Revista Brasileira de Paleontologia, 15:57-66. doi:10.4072/ rbp.2012.1.05

Almeida, B.A.; Silva, C.B.; Gimenes, M.R. \& Anjos, L. 2016. Waterbirds in a floodplain: influence of spatial and environmental factors through time. Revista Brasileira de Ornitologia, 24:314-322.

Andersen, K.K.; Svensson, A.; Johnsen, S.J.; Rasmussen, S.O.; Bigler, M.; Röthlisberger, R.; Ruth, U.; Sigaard-Andersen, M.L.; Steffensen, J.P.; Dahl-Jensen, D. Vinther, B.M. \& Clausen, H.B. 2006. The Greenland Ice Core Chronology 2005, 15-42ka. Part 1: constructing the time scale. Quaternary Science Reviews, 25:3246-3257. doi:10.1016/j.quascirev.2006.08.002

Aslan, A. \& Behrensmeyer, A.K. 1996. Taphonomy and time resolution of bone assemblages in a contemporary fluvial system: the East Fork River, Wyoming. Palaios, 11:411-421. doi:10.2307/3515209

Baumel, J.J. \& Witmer, L.M. 1993. Osteology. In: J.J. Baumel (ed.) Handbook of Avian Anatomy: Nomina Anatomica Avium. Cambridge, The Nuttal Ornithological Club, p. 45-132 (Publication 23).

Behrensmeyer, A.K. 1975. The taphonomy and paleoecology of PlioPleistocene vertebrate assemblages east of Lake Rudolf, Kenya. Bulletin of the Museum of Comparative Zoology, 146:473-578.

Behrensmeyer, A. K. 1978. Taphonomic and ecologic information from bone weathering. Paleobiology, 4:150-162. doi:10.1017/ S0094837300005820

Behrensmeyer, A.K. 1982. Time resolution in fluvial vertebrate assemblages. Paleobiology, 8:211-227. doi:10.1017/ S0094837300006941

Behrensmeyer, A.K. 1991. Terrestrial vertebrate accumulations. In: P.A. Allison \& D.R.G. Briggs (eds.) Taphonomy: releasing the data locked in the fossil record, Plenum Press, p. 291-329.

Behrensmeyer, A.K. \& Hook, R.W. 1992. Paleoenvironmental contexts and taphonomic modes. In: A.K. Behrensmeyer; J.D. Damuth; W.A. DiMichele; R. Potts; H.-D. Sues \& S.L. Wing (eds) Terrestrial ecosystems through time, The University of Chicago Press, p. 15-136.

Behrensmeyer, A.K.; Stayton, C.T. \& Chapman, R.E. 2003. Taphonomy and ecology of modern avifaunal remains from Amboseli Park, Kenya. Paleobiology, 29:52-70. doi:10.1666/0094-8373(2003)029\%3C0052:TAEOMA\%3E2 o. $\mathrm{CO} ; 2$

Bellairs, A.D'A. \& Jenkin, C.R. 1960. The skeleton of birds. In: A.J. Marshall (ed.) Biology and comparative biology of birds, Academic Press, p. 241-300.

Bencke, G.A.; Dias, R.A.; Bugoni, L.; Agne, C.E.; Fontana, C.S.; Maurício, G.N. \& Machado, D.B. 2010. Revisão e atualização da lista das aves do Rio Grande do Sul, Brasil. Iheringia (Série Zoologia), 100:519-556.

Bickart, K.J. 1984. A field experiment in avian taphonomy. Journal of Vertebrate Paleontology, 4:525-535.

Birkeland, P.W. 1974. Pedology, weathering and geomorphological research. New York, Oxford University Press, 285 p.

Birkeland, P.W. 1992. Quaternary soil chronosequences in various environments - extremely arid to humid tropical. In: I.P. Martini \& W. Chesworth (eds.) Weathering, soils and paleosols, Elsevier, p. 261-281.

Blasi, A.; Castiñera Latorre, C.; Del Puerto, L.; Prieto, A.R.; Fucks, E.; De Francesco, C.; Hanson, P.R.; García-Rodriguez, F.; Huarte, R.; Carbonari, J. \& Young, A. 2010. Paleoambientes 
de la cuenca del Río Luján (Buenos Aires, Argentina) durante el último período glacial (EIO 4-2). Latin American Journal of Sedimentology and Basin Analysis, 17:85-111.

Boas, J.E.V. 1929. Biologisch-anatomische Studien Huber den Hals der Vögel. Det Kongelige Danske Videnskabernes Selsk Skrifter Naturvidenskabelige og Mathematiske Afhandlinger, 9:105-222.

Brook, E.J. \& Buizert, C. 2018. Antarctic and global climate history viewed from ice cores. Nature, 558:200-208. doi:10.1038/ s41586-018-0172-5

Brunetto, E.; Ferrero, B.S. \& Noriega, J.I. 2015. Late Pleistocene lithostratigraphy and sequences in the southwestern Mesopotamia (Argentina): evidences of the Last Interglacial Stage. Journal of South American Earth Sciences, 58:111-128. doi:10.1016/j. jsames.2014.12.003

Caron, F. 2014. Estratigrafia e evolução da barreira holocênica na região costeira de Santa Vitória do Palmar, Planície Costeira do Rio Grande do Sul. Programa de Pós-Graduação em Geociências, Universidade Federal do Rio Grande do Sul, Ph.D. Thesis, 167 p.

Cenizo, M.; Agnolín, F.L. \& Pomi, L.H. 2015. ANew Pleistocene bird assemblage from the Southern Pampas (Buenos Aires, Argentina). Palaeogeography, Palaeoclimatology, Palaeoecology, 420:6581. doi:10.1016/j.palaeo.2014.12.009

Cione, A.L. \& Tonni, E.P. 1999. Biostratigraphy and chronological scale of upper-most Cenozoic in the Pampean Area, Argentina. In: J. Rabassa \& M. Salemme (eds.) Quaternary of South America and Antarctic Peninsula, A.A. Balkema, p. 23-51.

Clapperton, C.M. 1993. Quaternary geology and geomorphology of South America. Amsterdam, Elsevier Press, 779 p.

Coard, R. \& Dennell, R.W. 1995. Taphonomy of some articulated skeletal remains: transport potential in an artificial environment. Journal of Archaeological Science, 22:441-448. doi:10.1006/ jasc.1995.0043

Cruz, I. 2005. La representación de partes esqueléticas de aves. Patrones naturales e interpretación arqueológica. Archaeofauna, 14:69-81

Cuello, J.P. 1988. Lista de aves fósiles de la region neotropical y de las islas antillanas. Paula-Coutiana, 2:3-79.

D’Amore, D.V.; Stewart, S.R. \& Huddleston, J.H. 2004. Saturation, reduction, and the formation of iron-manganese concretions in the Jackson-Frazier wetland, Oregon. Soil Science Society of America Journal, 68:1012-1022.

Daubrée, A. 1879. Études synthétiques de géologie expérimentale. Geological Magazine, 6:248-259.

Davey, B.G.; Russell, J.D. \& Wilson, M.J. 1975. Iron oxide and clay minerals and their relation to colours of red and yellow podzolic soils near Sydney, Australia. Geoderma, 14:125-138. doi:10.1016/0016-7061(75)90071-3

Davis, P.G. \& Briggs, D.E.G. 1998. The impact of decay and disarticulation on the preservation of fossil birds. Palaios, 13:3-13. doi: 10.2307/3515277

Dias, R.A. \& Burguer, M.I. 2005. A assembléia de aves de áreas úmidas em dois sistemas de cultivo de arroz irrigado no extremo sul do Brasil. Ararajuba, 13:63-80.

Diederle, J.M. \& Noriega, J.I. 2013. Aves del Mioceno de la Provincia de Entre Ríos, Argentina. In: D. Brandoni \& J.I. Noriega (eds.) El Neógeno de la Mesopotamia Argentina, Buenos Aires, Asociación Paleontológica Argentina, p. 97-108 (Publicación Especial 14).

Dyke, G. \& Lindow, B.E.K. 2009. Taphonomy and abundance of birds from the Lower Eocene Fur Formation of Denmark. Geological Journal, 44:365-373. doi:10.1002/gj.1150
Elliott, A. 1992. Ciconiidae. In: J. del Hoyo; A. Elliott \& J. Sargatal (eds.) Handbook of the birds of the World, Lynx Editions, p. 436-465.

Emslie, S.D. 1998. Avian community, climate, and sea-level changes in the Plio-Pleistocene of the Florida peninsula. Ornithological Monographs, 50:1-113p. doi:10.2307/40166707

EPICA Community Members. 2006. One-to-one coupling of glacial climate variability in Greenland and Antarctica. Nature, 444:195-198. doi:10.1038/nature05301

Erickson, P.G.P. 1987. Interpretations of archaeological bird remains: a taphonomic approach. Journal of Archaeological Science, 14:65-75. doi:10.1016/S0305-4403(87)80006-7

Evans, L.J. 1992. Alteration products at the Earth's surface - the clay minerals. In: I.P. Martini \& W. Chesworth (eds.) Weathering, soils and paleosols, Elsevier, p. 107-126.

Feduccia, J.A. 1967. Ciconia maltha and Grus americana from the Upper Pliocene of Idaho. The Wilson Bulletin, 79:316-318.

Fernández-Jalvo, Y. \& Andrews, P. 2003. Experimental effects of water abrasion on bone fragments. Journal of Taphonomy, 1:147-163.

Gardner, E.E.; Walker, S.E. \& Gardner, L.I. 2016. Palaeoclimate, environmental factors, and bird body size: a multivariable analysis of avian fossil preservation. Earth-Science Reviews, 162:177-197. doi:10.1016/j.earscirev.2016.07.001

Gasparini, G.M.; Rabassa, J.; Deschamps, C. \& Tonni, E.P. 2016. Marine Isotope Stage 3 in Southern South America, $60 \mathrm{ka}$ B.P.-30 ka B.P. Switzerland, Springer 354 p. doi:10.1007/9783-319-40000-6

Gimenes, R.M. \& Anjos, L. 2006. Influence of lagoons size and prey availability on the wading birds (Ciconiiformes) in the upper Paraná River floodplain, Brazil. Brazilian Archives of Biology and Technology, 49 463-473. doi:10.1590/S151689132006000400015

Golden, D.C.; Chen, C.C.; Dixon, J.B. \& Tokashiki, Y. 1988. Pseudomorphic replacement of manganese oxides by iron oxide minerals. Geoderma, 42:199-211.

Hancock, J.A.; Kushlan, J.A. \& Kahl, M.P. 1992. Storks, ibises, and spoonbills of the World. London, Academic Press, p. 91-95.

Hanson, C.B. 1980. Fluvial taphonomic processes: models and experiments. In: A.K. Behrensmeyer \& A.P. Hill (eds.) Fossils in the making - Vertebrate taphonomy and paleoecology, The University of Chicago Press, p. 156-181.

Hett, W.S. 1955. Aristotle - Minor Works. Cambridge, Harvard University Press, 528 p.

Hill, A.P. 1980. Early postmortem damage to the remains of some contemporary east African mammals. In: A.K. Behrensmeyer \& A.P. Hill (eds.) Fossils in the making - Vertebrate taphonomy and paleoecology, The University of Chicago Press, p. 131-152.

Hsiou, A.S. 2009. O registro fóssil de répteis e aves no Pleistoceno final do estado do Rio Grande do Sul, Brasil. In: A.M. Ribeiro; S.G. Bauermann \& C.S. Scherer (eds.) Quaternário do Rio Grande do Sul: Integrando Conhecimentos, Porto Alegre, Sociedade Brasileira de Paleontologia, p. 143-154 (Monografias 2).

Huxley, T.H. 1872. Anatomy of Vertebrated Animals. New York, D. Appleton and Co., $431 \mathrm{p}$.

Iriondo, M.H. 1999. Climatic changes in the South American plains: records of a continental-scale oscillation. Quaternary International, 57/58:93-112. doi:10.1016/S10406182(98)00053-6

Johnson, R.G. 1960. Models and methods for analysis of the mode of formation of fossil assemblages. Bulletin of the Geological 
Society of America, 71:1075-1086. doi:10.1130/00167606(1960)71[1075:MAMFAO]2.0.CO;2

Jouzel, J. et al. 2007. Orbital and millennial Antarctic climate variability over the past 800,000 years. Science, 317:793-796. doi:10.1126/science. 1141038

Kerber, L.; Lopes, R.P.; Oliveira, E.V.; Ribeiro, A.M. \& Pereira, J.C. 2012. On the presence of Holochilus brasiliensis (Desmarest, 1819) (Rodentia: Cricetidae: Sigmodontinae) in the late Pleistocene of southern Brazil. Gaea, 8:47-54. doi:10.4013/ gaea.2012.82.02

Krumbein, W.C. 1941a. Measurement and geological significance of shape and roundness of sedimentary particles. Journal of Sedimentary Research, 11:64-72. doi:10.1306/d42690f3-2b2611d7-8648000102c1865d

Krumbein, W.C. 1941b. The effects of abrasion on the size, shape and roundness of rock fragments. The Journal of Geology, 49:482-520. doi:10.1086/624985

Lemieux-Dudon, B.; Blayo, E.; Petit, J-R.; Waelbroek, C.; Svensson, A.; Ritz, C.; Barnola, J-M.; Narcisi, B.M. \& Parrenin, F. 2010. Consistent dating for Antarctic and Greenland ice cores. Quaternary Science Reviews, 29:8-20. doi:10.1016/j. quascirev.2009.11.010

Lima, L.G.; Dillenburg, S.R.; Medeanic, S.; Barboza, E.G.; Rosa, M.L.C.C.; Tomazelli, L.J.; Dehnhardt, B.A. \& Caron, F. 2013. Sea-level rise and sediment budget controlling the evolution of a transgressive barrier in southern Brazil. Journal of South American Earth Sciences, 42:27-38. doi:10.1016/j. jsames.2012.07.002

Lisiecki, L.E. \& Raymo, M.E. 2005. A Pliocene-Pleistocene stack of 57 globally distributed benthic $\delta^{18} \mathrm{O}$ records. Paleoceanography, 20:PA1003. doi:10.1029/2004PA001071

Livingston, S.D. 1989. The taphonomic interpretation of avian skeletal part frequencies. Journal of Archaeological Science, 16:531-541. doi:10.1016/0305-4403(89)90072-1

Lopes R.P. 2013. Biostratigraphy of the Pleistocene fossiliferous deposits of southern Brazilian coastal area. Journal of Mammalian Evolution, 20:69-82. doi:10.1007/s10914-0119173-y

Lopes, R.P.; Buchmann, F.S.C. \& Caron, F. 2006. Primeiro registro de fósseis de aves marinhas na Planície Costeira do Rio Grande do Sul, Brasil. Revista Brasileira de Geociencias, 36:648-650.

Lopes, R.P. \& Ferigolo, J. 2015. Post mortem modifications (pseudopaleopathologies) in Middle-Late Pleistocene mammal fossils from Southern Brazil. Revista Brasileira de Paleontologia, 18:285-306. doi:10.4072/rbp.2015.2.09

Lopes, R.P., Dillenburg, S.R. \& Schultz, C.L. 2016a. Cordão Formation: loess deposits in the southern coastal plain of the state of Rio Grande do Sul. Brazil. Anais da Academia Brasileira de Ciências, 88:2143-2166. doi:10.1590/0001-3765201620150738

Lopes, R.P.; Dillenburg, S.R.; Schultz, C.L.; Ferigolo, J.; Ribeiro, A.M.; Pereira, J.C.; Holanda, E.C.; Pitana, V.G.; \& Kerber, L. 2014b. The sea-level highstand correlated to marine isotope stage (MIS) 7 in the coastal plain of the state of Rio Grande do Sul, Brazil. Anais da Academia Brasileira de Ciências, 86:1573-1595. doi:10.1590/0001-3765201420130274

Lopes, R.P.; Kinoshita, A.; Baffa, O.; Figueiredo, A.M.G.; Dillenburg, S.R.; Schultz, C.L. \& Pereira, J.C. 2014a. ESR dating of Pleistocene mammals and marine shells from the coastal plain of Rio Grande do Sul state, Southern Brazil. Quaternary International, 352:124-134. doi:10.1016/j.quaint.2013.07.020

Lopes, R.P.; Oliveira, L.C.; Figueiredo, A.M.G.; Kinoshita, A.; Baffa, O. \& Buchmann, F.S.C. 2010. ESR dating of Pleistocene mammal teeth and its implications for the biostratigraphy and geological evolution of the coastal plain, Rio Grande do Sul, southern Brazil. Quaternary International, 212:213-222. doi:10.1016/j. quaint.2009.09.018

Lopes, R.P.; Pereira, J.C.; Souza, M.S.; Raupp, S.V. \& Dillenburg, S.R. 2016b. Diatoms from Late Pleistocene-Early Holocene diatomites of the southern coastal plain of Rio Grande do Sul state, southern brazil coastal plain of Rio Grande do Sul state, Brazil. In: CONGRESO LATINOAMERICANO DE PALEONTOLOGÍA, 9, 2016. Libro de Resúmenes, Lima, p. 125.

Lopes, R.P.; Ribeiro, A.M.; Dillenburg, S.R. \& Schultz, C.L. 2013. Late Middle to Late Pleistocene paleoecology and paleoenvironments in the coastal plain of Rio Grande do Sul state, Southern Brazil, from stable isotopes in fossils of Toxodon and Stegomastodon. Palaeogeography, Palaeoclimatology, Palaeoecology, 369:385-394. doi:10.1016/j.palaeo.2012.10.042

Miall, A.D. 1985. Architectural-element analysis: a new method of facies analysis applied to fluvial deposits. Earth-Science Reviews, 22:261-308. doi:10.1016/0012-8252(85)90001-7

Miall, A.D. 2006. The geology of fluvial deposits. Berlin, SpringerVerlag, 582 p. doi:10.1007/978-3-662-03237-4

Miller, L.H. 1912. Contributions to avian palaeontology from the Pacific coast of North America. Bulletin of the Department of Geology, 7:61-115.

Mitchell, J.S. 2015. Preservation is predictable: quantifying the effect of taphonomic biases on ecological disparity in birds. Paleobiology, 41:353-367. doi:10.1017/pab.2014.23

Noriega, J.I. \& Agnolín, F. 2008. El registro paleontológico de las Aves del "Mesopotamiense" (Formación Ituzaingó; Mioceno tardio-Plioceno) de la provincia de Entre Ríos, Argentina. Tucumán, INSUGEO, p. 271-290 (Miscelánea 17).

Noriega, J.I. \& Cladera, G. 2008. First record of an extinct marabou stork in the Neogene of South America. Acta Palaeontologica Polonica, 53:593-600. doi:10.4202/app.2008.0404

Olson, S.L. 1985. The fossil record of birds. In: D.S. Farner; J.R. King \& K.C. Parkes (eds.) Avian Biology, Academic Press p.79-238.

Olson, S.L. 1991. The fossil record of the genus Mycteria (Ciconiidae) in North America. The Condor, 93:1004-1006. doi: $10.2307 / 3247735$

Olson, S.L. \& Rasmussen, D.T. 1986. The paleoenvironment of the earliest hominoids: new evidence from the Oligocene avifauna of Egypt. Science, 233:1202-1204. doi:10.1126/ science.233.4769.1202

Owen, R. 1866. On the anatomy of vertebrates. London, Longmans, Green, and Co., 592 p.

Pardiñas, U.F.J.; Gelfo, J.N.; San Cristóbal, J.; Cione, A.L. \& Tonni, E.P. 1996. Una asociación de organismos marinos y continentales en el Pleistoceno superior del sur de la provincia de Buenos Aires, Argentina. In: CONGRESO GEOLÓGICO ARGENTINO, 12, 1996. Actas, p. 95-111.

Parker, W.K. 1887. On the vertebral chain of birds. Proceedings of the Royal Society of London, 43:465-482. doi:10.1098/ rspl.1887.0169

Paula Couto, C. \& Cunha, F.L.S. 1965. Nota preliminar sobre o reconhecimento geo-paleontológico do Rio Grande do Sul. Rio de Janeiro, Departamento Nacional de Produção Mineral, Divisão de Geologia e Mineralogia, p. 49-50 (Boletim 40).

Pereira, J.C.; Lopes, R.P. \& Kerber, L. 2012. New remains of Late Pleistocene mammals from the Chuí Creek, southern Brazil. Revista Brasileira de Paleontologia, 15:228-239. doi:10.4072/ rbp.2012.2.10 
Pettijohn, F.J. 1957. Sedimentary Rocks. Bombay, Orient Longmans Private Ltd., 718 p.

Rasmussen, D.T.; Olson, S.L. \& Simons, E.L. 1987. Fossil birds from the Oligocene Jebel Qatrani Formation, Fayum Province, Egypt. Smithsonian Contributions to Paleobiology, 62:1-20. doi:10.5479/si.00810266.62.1

Ribeiro, A.M.; Alvarenga, H.M. \& Rosenau, M. 1995. Primeiro registro de ave fóssil para a Formação Touro Passo (Pleistoceno superior-Holoceno inferior) do Rio Grande do Sul. In: CONGRESSO BRASILEIRO DE PALEONTOLOGIA, 14, 1995. Atas, Uberaba, SBP, p. 107.

Rich, P.V. 1980. Preliminary report on the fossil avian remains from Late Tertiary sediments at Langebaanweg (Cape Province), South Africa. South African Journal of Science, 76:166-170.

Schmitz, P.I.; Girelli, M. \& Rosa, A.O. 1997. Pesquisas arqueológicas em Santa Vitória do Palmar, RS. In: P.I. Schmitz (ed.) Arqueologia do Rio Grande do Sul, Brasil, São Leopoldo, Instituto Anchietano de Pesquisas, UNISINOS, 95 p. (Documentos 7).

Schwertmannn, U. 1993. Relation between iron oxides, soil color, and soil formation. In: J.M. Bigham; E.J. Ciolkosz \& U. Schwertmann (eds.) Relations Between iron oxides, soil color, and soil formation, Madison, Soil Science Society of America, p. 51-69. (Special Publication 31). doi:10.2136/sssaspecpub31.c4

Shufeldt, R. 1909. Osteology of birds. New York State Museum Bulletin, 130:270-344.

Soil Sicence Division Staff. 2017. Soil Survey Manual. Madison, United States Department of Agriculture, $603 \mathrm{p}$.

Soliani Jr, E. 1973. Geologia da região de Santa Vitória do Palmar, RS, e a posição estratigráfica dos fósseis de mamíferos pleistocênicos. Programa de Pós-Graduação em Geociências, Universidade Federal do Rio Grande do Sul, MSc Dissertation, 88 p. (Unpublished).

Stiles, C.A.; Mora, C.I. \& Driese, S.G. 2001. Pedogenic iron-manganese nodules in vertisols: a new proxy for paleoprecipitation? Geology, 29:943-946. doi:10.1130/00917613(2001)029<0943:PIMNIV>2.0.CO;2

Tambussi, C. 2011. Palaeoenvironmental and faunal inferences based on the avian fossil record of Patagonia and Pampa: what works and what does not. Biological Journal of the Linnean Society, 103:458-474. doi:10.1111/j.1095-8312.2011.01658.x

Tambussi, C. \& Degrange, F.J. 2013. South American and Antarctic continental Cenozoic birds - Paleobiogeographic affinities and disparities. Dordrecht, Springer, 113 p. doi:10.1007/978-94007-5467-6

Tambussi, C. \& Noriega, J. 1996. Summary of the avian fossil record from southern South America. Münchner Geowissenschaftliche Abhandlungen (A), 30:245-264.

Tambussi, C.; Noriega, J. \& Tonni, E.P. 1993. Late Cenozoic birds of Buenos Aires Province (Argentina): an attempt to document quantitative faunal changes. Palaeogeography, Palaeoclimatology, Palaeoecology, 101:117-129. doi:10.1016/0031-0182(93)90155-C
Tambussi, C.; Ubilla, M.; Hospitaleche, C.A. \& Perea, D. 2005. Fossil records and paleoenvironmental implications of Chloephaga picta (Gmelin, 1789) (Magellan Goose) and Cariama cristata (Linnaeus, 1766) (Seriema) from the Late Pleistocene of Uruguay. Neues Jahrbuch für Geologie und Paläontologie, 5:257-268.

Trapani, J. 1998. Hydrodynamic sorting of avian skeletal remains. Journal of Archaeological Science, 25:477-487. doi:10.1006/ jasc.1997.0257

Tyrberg, T. 2008. The Late Pleistocene Continental Avian extinction - an evaluation of the fossil evidence. Oryctos, 7:249-269.

Ubilla, M. \& Martínez, S. 2016. Geology and Paleontology of the Quaternary of Uruguay. Dordrecht, Springer, $77 \mathrm{p}$. doi:10.1007/978-3-319-29303-5

Urbina, M. \& Stucchi, M. 2005. Evidence of a fossil stork (Aves: Ciconiidae) from the Late Miocene of the Pisco Formation, Peru. Boletin de la Sociedad Geológica del Perú, 100:63-66.

Vepraskas, M.J. 2015. Redoximorphic features for identifying aquic conditions. Raleigh, North Carolina Agricultural Research Service, 29 p. (Technical Bulletin 301).

Villwock, J.A. \& Tomazelli, L.J. 1995. Geologia costeira do Rio Grande do Sul. Notas Técnicas, 8:1-45.

Voorhies, M.R. 1969. Taphonomy and populations dynamics of an early Pliocene vertebrate fauna, Knox County, Nebraska. Wyoming, Rocky Mountain Geology, 69 p. (Special Paper 1). doi:10.2113/gsrocky.8.special_paper_1.1

Vuilleumer, F. 1985. Fossil and Recent Avifaunas and the Interamerican interchange. In: F.G. Stehlis \& D. Webb (eds.) The great American biotic interchange, Springer, p. 387-424.

Wallinga, J.; Murray, A. \& Wintle, A. 2000. The single-aliquot regenerative-dose (SAR) protocol applied to coarse-grain feldspar. Radiation Measurements, 32:529-533.

Wentworth, C.K. 1919. A laboratory and field study of cobble abrasion. The Journal of Geology, 27:507-521. doi:10.1086/622676

Wolff, E.W.; Fischer, H. \& Röthlisberger, R. 2009. Glacial terminations as southern warmings without northern control. Nature Geoscience, 2:206-209. doi:10.1038/ngeo442

Zingg, T. 1935. Beitrag zur Schotteranalyse. Schweizerische Mineralogische und Petrographische Mitteilungen, 15:39-140.

Received in 13 June, 2019; accepted in 06 October, 2019. 